\title{
The Effect of Formulary Restrictions on Patient and Payer Outcomes: A Systematic Literature Review
}

\author{
Yujin Park, PharmD; Syed Raza, MS; Aneesh George, MS; \\ Rumjhum Agrawal, MPharm; and John Ko, PharmD, MS
}

\begin{abstract}
BACKGROUND: Formulary restrictions are implemented to reduce pharmacy costs and ensure appropriate use of pharmaceutical products. As adoption of formulary restrictions increases with rising pharmacy costs, there is a need to better understand the potential effect of formulary restrictions on patient and payer outcomes.
\end{abstract}

OBJECTIVE: To conduct a systematic literature review that assesses the effect of formulary restrictions on the following outcomes: medication adherence, clinical outcomes, treatment satisfaction, drug utilization, health care resource utilization, and economic outcomes.

METHODS: Studies published in 2005 or later were identified from the MEDLINE, Embase, and Cochrane databases and the National Health Service Economic Evaluation Database, using 2 sets of search terms. A total of 17 formulary restriction terms (e.g., step therapy [ST] and prior authorization [PA]) and 55 outcome terms were included, resulting in 935 unique search term combinations. Two reviewers independently conducted analyses of the titles, abstracts, and full-text articles. The search was limited to English-language articles that evaluated the effect of ST and/or PA placed by U.S. third-party payers on the following outcomes: patient outcomes (medication adherence, clinical outcomes, and treatment satisfaction) and payer outcomes (drug utilization, health care resource utilization, and economic outcomes).

RESULTS: Of 2,321 reviewed articles, 59 articles met the study inclusion criteria. The included studies assessed the effect of ST $(n=18), P A(n=35)$, or both $(n=6)$ on medication adherence $(n=14)$, clinical outcomes $(n=12)$, treatment satisfaction $(n=2)$, drug utilization $(n=39)$, health care resource utilization $(n=18)$, and economic outcomes $(n=42)$. The 59 articles measured 164 outcomes across the patient, health care resource utilization, and economic outcome categories of interest. Of the total number of outcomes, $50.6 \%(n=83)$ were negative in direction or were unfavorable, whereas $40.2 \%(n=66)$ were positive in direction or were favorable, when the perspectives of patients and payers were considered. Of the total number of drug utilization outcomes reported $(n=46)$, the majority showed lower drug utilization $(>90 \%)$. However, in some of the articles, pharmacy cost savings resulting from lower drug utilization appeared to be offset by increased medical costs.

CONCLUSIONS: Formulary coverage decisions may have unintended consequences on patient and payer outcomes despite lower drug utilization and pharmacy cost savings; therefore, careful evaluation of restrictions before policy implementation and continued reevaluation after implementation is warranted.

\section{J Manag Care Spec Pharm. 2017;23(8):893-901}

Copyright $\odot 2017$, Academy of Managed Care Pharmacy. All rights reserved.

\section{What is already known about this subject}

Formulary restrictions have been shown to reduce drug utilization, leading to pharmacy cost savings; however, the unintended consequences of such restrictions on patients and payers are relatively less understood.

Although previous literature has summarized the evidence on unintended consequences of formulary restrictions, there is a need to evaluate the comprehensive list of patient and payer outcomes.

\section{What this study adds}

This study evaluated a comprehensive list of patient outcomes (medication adherence, clinical outcomes, and treatment satisfaction) and payer outcomes (health care resource utilization and economic outcomes).

Formulary restrictions are associated with reduced medication adherence and negative clinical outcomes in patients.

Although formulary restrictions reduce drug utilization and associated drug costs, resulting in pharmacy cost savings, some of these cost savings may be offset by increased health care resource utilization and medical costs.

$\mathrm{H}$ ealth care expenditure in the United States is increasing every year and more than doubled from the years 2000 to 2015. National health care expenditure in 2015 was approximately $\$ 3.2$ trillion, and in the same year, expenditure on prescription drugs comprised $10.1 \%$ of the national health care expenditure. ${ }^{1}$ Increases in health care expenditures are partly related to third-party payment systems because patient perceptions of relatively low out-of-pocket costs has led to increased demand for medical services, thereby driving up costs and creating additional layers of expenditures because of more administrative tasks for providers, employers, and third-party payers. ${ }^{2}$ When the Medicare and Medicaid systems first came into existence in the 1960s, out-of-pocket costs were greater than third-party payments; however, since then, there has been a steady increase in the use of third-party payment models and a subsequent decrease in out-of-pocket costs for patients. ${ }^{3,4}$

Because of increasing health care spending in the United States, third-party payers introduced various techniques aimed at controlling rising health care costs, and organizations such 
as managed care organizations (MCOs) and pharmacy benefit managers came into existence. These organizations essentially control financing and delivery of health care services, in association with selected providers, by monitoring quality and use of health care services. ${ }^{5}$ The purpose of MCOs, pharmacy benefit managers, and employer-sponsored plans is to reduce costs and use of prescription drugs and other health care services, while providing quality service. ${ }^{6,7}$

Regarding prescription drugs, commonly used pharmacy management policies by third-party payers include formulary restrictions through implementation of prior authorization (PA), step therapy (ST) or step edit, cost sharing, cap drug benefits, and preferred drug lists (PDLs). ${ }^{6} \mathrm{PA}$ involves acquiring advance approval from a health insurance plan before reimbursement can occur for a medication, and ST involves the use of other lower-cost alternatives before payment is authorized by a health insurance plan. ${ }^{8,9}$

Formulary restrictions are designed and implemented to reduce costs and use of prescription drugs ${ }^{10-13}$ and have been shown to be effective in a number of literature reviews. ${ }^{14-18}$ Motheral (2011) conducted a critical review of the literature, ${ }^{18}$ including 14 studies on ST interventions, and concluded that the ST programs resulted in significant pharmacy cost savings and reduced drug utilization. Although all of the reviews evaluated the effect of formulary restrictions on drug utilization and costs, each review also emphasized the importance of identifying the unintended effects of formulary restrictions on outcomes such as drug compliance and clinical, economic, and humanistic outcomes.

Studies have also reported unintended consequences of managed care formulary restrictions on health outcomes. ${ }^{19-24}$ Mark et al. (2010) evaluated the effect of ST on antidepressant users in employer plans and reported a $4.7 \%$ increase in outpatient office visits, a $17 \%$ higher number of inpatient admissions, and a $37 \%$ increase in the number of emergency room (ER) visits. ${ }^{19}$ A retrospective study conducted by Johnston et al. (2014) assessed the effect of pregabalin PA on clinical outcomes and reported 59.8\% higher odds of medication-medication and medication-condition interactions in the pregabalin PA group compared with the non-PA group. ${ }^{23}$ Moreover, additional literature reviews have investigated unintended effects of formulary restrictions on outcomes such as clinical outcomes, medication adherence, health care resource utilization, and economic outcomes. ${ }^{14-16,25,26}$

Although previous literature reviews have summarized the evidence on unintended consequences of formulary restrictions for some outcomes, there is a need to evaluate the evidence on the effect of formulary restrictions on a range of outcomes systematically. Although previous literature reviews have delved into this topic, their approach was either not systematic in terms of methodology (e.g., not covering a variety of biomedical databases) or not comprehensive in terms of the range of outcomes evaluated (e.g., medication adherence and clinical, economic, health care resource utilization, and patientreported outcomes); they also did not assess the overall directional positive or negative impact of the outcomes. ${ }^{14-16,25}$ Only 1 recent systematic review assessed the directional effect of formulary restrictions on patient and payer outcomes and evaluated a variety of formulary restrictions, including cost sharing, quantity limits, PDLs, ST, and PA. ${ }^{26}$ Considering the increased use of formulary restrictions such as ST and PA, there is a growing need to evaluate their effect on a range of health outcomes; therefore, we aimed to use this systematic literature review (SLR) to assess the effect of PA and/or ST on the following outcomes: medication adherence, clinical outcomes, treatment satisfaction, drug utilization, health care resource utilization, and economic outcomes.

\section{Methods}

\section{Search Strategy}

This SLR was conducted using the OVID platform in the following databases: Embase (1996-February 23, 2017); MEDLINE without revisions (1996-February 23, 2017); MEDLINE inprocess and other nonindexed citations (February 23, 2017); EBM Reviews-Cochrane Database of Systematic Reviews (2005-February 22, 2017); EBM Reviews-Cochrane Central Register of Controlled Trials (January 2017); and EBM Reviews-NHS Economic Evaluation Database (first quarter 2017). The search strategy comprised 2 sets of terms: (1) formulary restriction and (2) patient and payer outcomes. Seventeen formulary restriction terms (e.g., step therap*, prior authoriz*, step edit*, fail-first, utilization manag*) and 55 outcome terms (e.g., healthcare utiliz*, economic outcome*, inpatient*, readmission*, emergency room visit*, adherence, discontinu*, effic*, safety, adverse event*, and patient outcome*) were combined. The search was limited to English-language articles published from 2005 onward. Duplicates of citations (due to overlap in the coverage of the databases) were excluded. Manual searches of bibliographies of relevant systematic review articles were also performed to identify all potentially relevant articles.

\section{Study Selection}

Studies reporting the effect of PA and/or ST on patient outcomes (medication adherence, clinical outcomes, and treatment satisfaction) and payer outcomes (health care resource utilization and economic outcomes) with or without drug utilization outcomes, irrespective of disease area, were included. Reviews, letters, commentaries, economic modeling studies, studies with mixed results from different formulary restrictions, and studies only assessing the effect of formulary restrictions on drug utilization without any other outcome of interest were excluded. The outcomes assessed were medication adherence, including persistence, adherence, compliance, and discontinuation; clinical outcomes, including effectiveness and adverse events; 


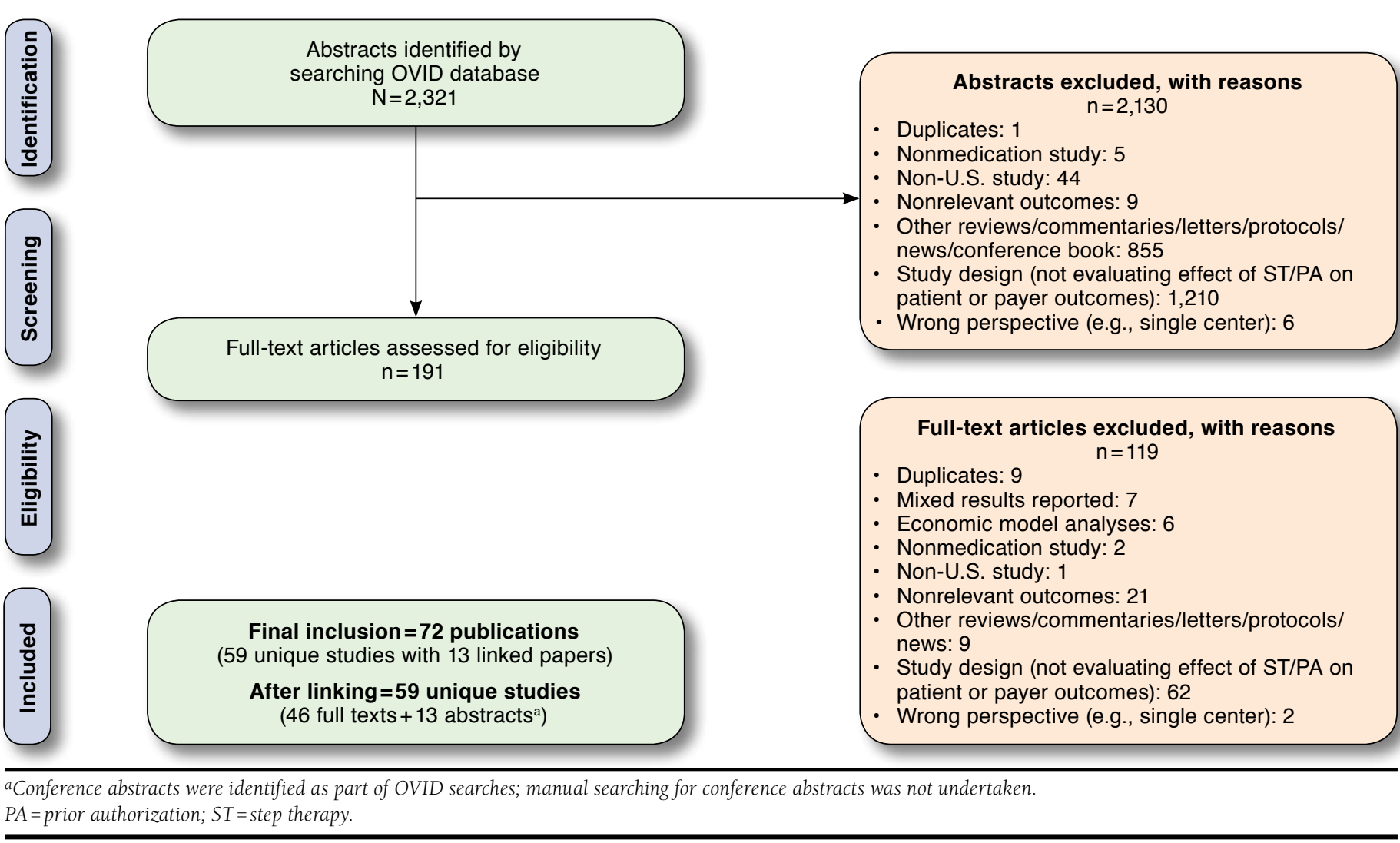

patient-reported outcomes, including treatment satisfaction, treatment preference, and quality of life; health care resource utilization, including outpatient visits, hospitalizations, and ER visits; economic outcomes, including medical costs, pharmacy costs, and total costs; and drug utilization data, whenever reported along with patient- or payer-related outcomes.

All of the studies retrieved from the literature search were screened by 2 independent reviewers based on the title and abstract supplied with each citation. Any discrepancy between the reviewers was resolved through a third independent reviewer. The inclusion/exclusion criteria were uniformly applied across all studies. Studies that did not meet the eligibility criteria were excluded, and the reasons for exclusion were documented. Similar to the screening of articles based on title and abstract, full-text articles were screened, and subsequently studies that met the eligibility criteria were subjected to data extraction.

Studies with multiple publications were linked to one another and extracted as a single study. Data extraction of the included studies was performed by 1 reviewer, and the quality of the data was checked by the second reviewer, with reconciliation of any differences through a third independent reviewer.
Studies showing improvement in outcomes because of formulary restrictions were considered positive (from a patient perspective [e.g., improved adherence, persistence, efficacy, and safety] and from a payer perspective [e.g., lower health care resource utilization and costs]). Studies showing worsening of patient or payer outcomes were considered negative (from a patient perspective [e.g., worsened adherence, persistence, efficacy, and safety] or a payer perspective [e.g., higher health care resource utilization and costs]). Positive or negative association of an outcome was further categorized based on its statistical significance. Finally, if there was no effect on the previously mentioned outcomes, those outcomes were considered neutral.

\section{Quality Assessment}

Each included full-text article was assessed for methodological quality. Studies that met the eligibility criteria for the review were critically appraised for quality based on their study designs, using the Cochrane risk of bias tool for randomized controlled trials (RCTs), the Newcastle-Ottawa Scale for cohort and case-control studies, the Effective Practice and Organisation of Care risk of bias criteria for interrupted time-series studies, and the Critical Appraisal Skills Programme checklist for cross-sectional studies. ${ }^{27-30}$ 


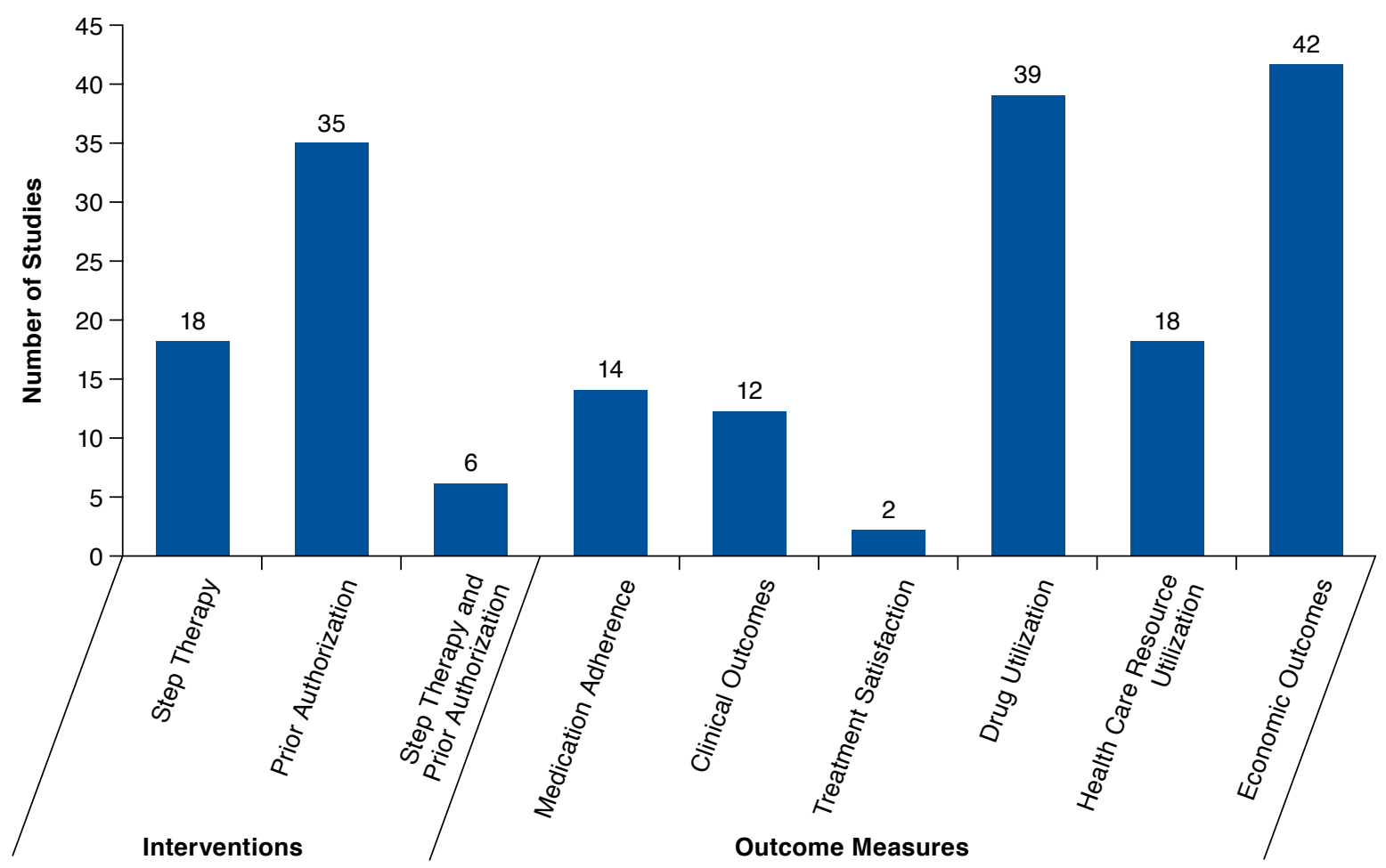

\section{Results}

The literature search yielded 2,321 publications and resulted in the inclusion of 59 unique studies (Figure 1). 10,19-24,31-82 In total, 48 retrospective observational studies, 5 time-series analysis studies, 3 cross-sectional studies, 1 case-control study, 1 controlled before-after study, and 1 RCT were included (Appendix A, available in online article). The majority of the included studies evaluated the PA restriction, followed by the ST restriction, or both of the restrictions (Figure 2). The most frequently reported outcome in the included studies was economic outcomes, followed by drug use, health care resource utilization, medication adherence, clinical outcome, and treatment satisfaction (Figure 2).

From all of the studies published as full text that were assessed for quality assessment, the quality score for retrospective observational studies ranged from 3 to 7 stars on the Newcastle-Ottawa Scale (Appendix B, available in online article), ${ }^{28}$ whereas assessment of time-series studies using the Effective Practice and Organisation of Care criteria yielded a "low risk" on the majority of the questions for all 5 of the studies. ${ }^{29}$ Two of the cross-sectional studies reported clear information as per the Critical Appraisal Skills Programme criteria. ${ }^{30}$ Only 1 RCT reported overall unclear risk of bias according to the Cochrane risk of bias tool. ${ }^{27}$
The 59 studies measured 164 outcomes across the patient, health care resource utilization, and economic outcome categories, as well as 46 outcomes for drug use. Of the total number of patient, health care resource utilization, and economic outcomes $(n=164), 50.6 \%$ were negative in direction or were unfavorable ( $\mathrm{n}=83) ; 40.2 \%$ were positive in direction or were favorable $(n=66)$; and $9.1 \%$ were neutral $(n=15)$. Across all of the negative outcomes $(n=83)$, statistical significance was reported in more than half of the studies $(n=47,56.6 \%)$; statistical significance was reported in half of the studies for all of the positive outcomes $(n=33,50 \%)$. On the other hand, for drug utilization outcomes $(n=46)$, more than $90 \%$ of the outcomes were positively associated with formulary restrictions $(n=42)$, and less than $10 \%$ were negatively associated $(n=4$; Figure $3 \mathrm{~A}$ ).

Of all of the outcome types, the majority were negatively associated with formulary restrictions (medication adherence [70.6\%], clinical outcome [91.7\%], patient-reported outcomes [treatment satisfaction, 100\%], health care resource utilization [outpatient visits, $82.4 \%$, and hospitalization, $64.7 \%$ ], and economic outcomes [medical costs, 66.6\%]). However, for pharmacy costs under economic outcomes and drug utilization, 83.3\% and $91.3 \%$ of outcomes reported positive association with formulary restrictions compared with negative or neutral association, respectively. A subset of studies $(n=20)$ that 


\section{FIGURE 3 Directional Effect of Formulary Restrictions}

\section{A. Patient and Payer Outcomes}

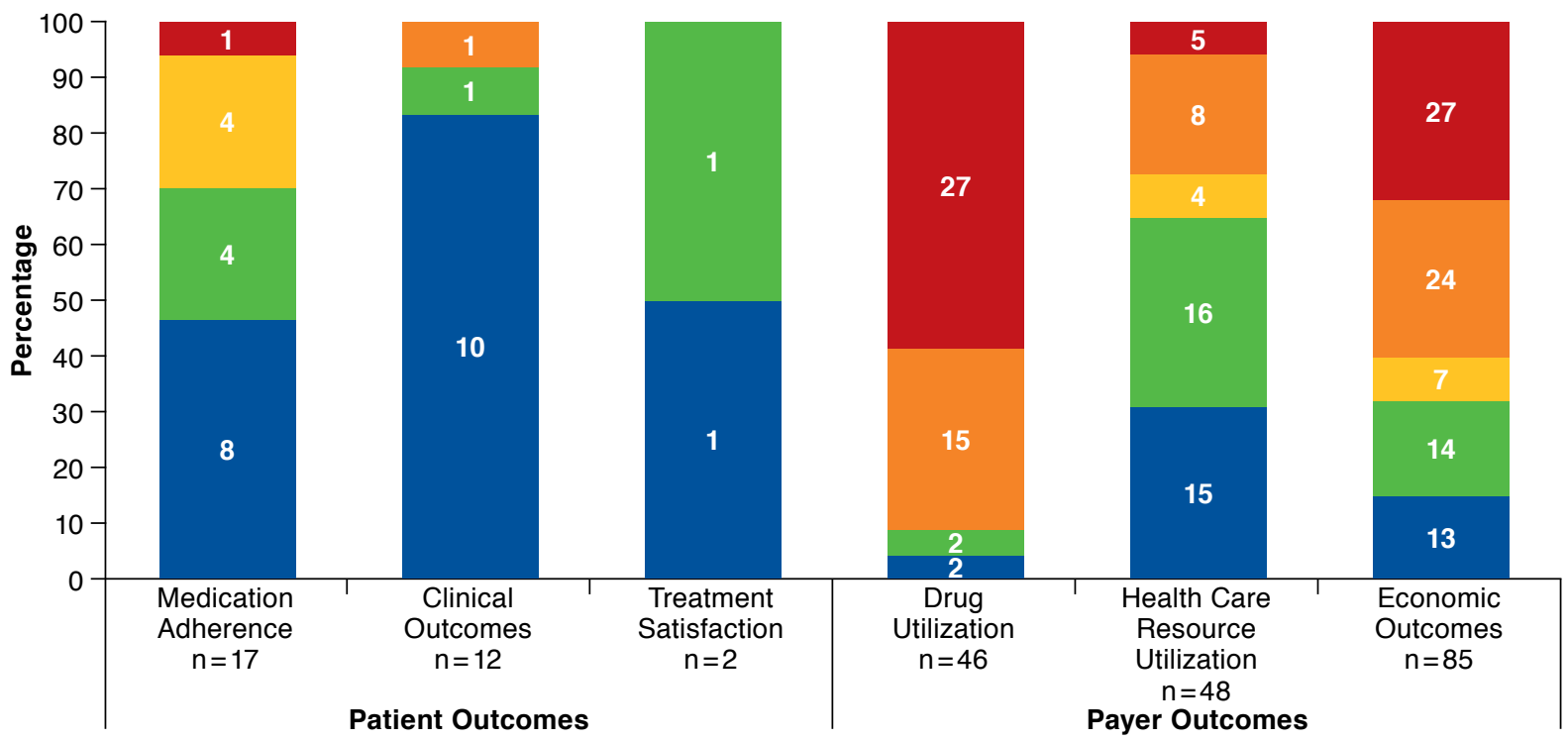

\section{B. Health Care Resource Utilization and Economic Outcomes (Detailed Payer Outcomes)}

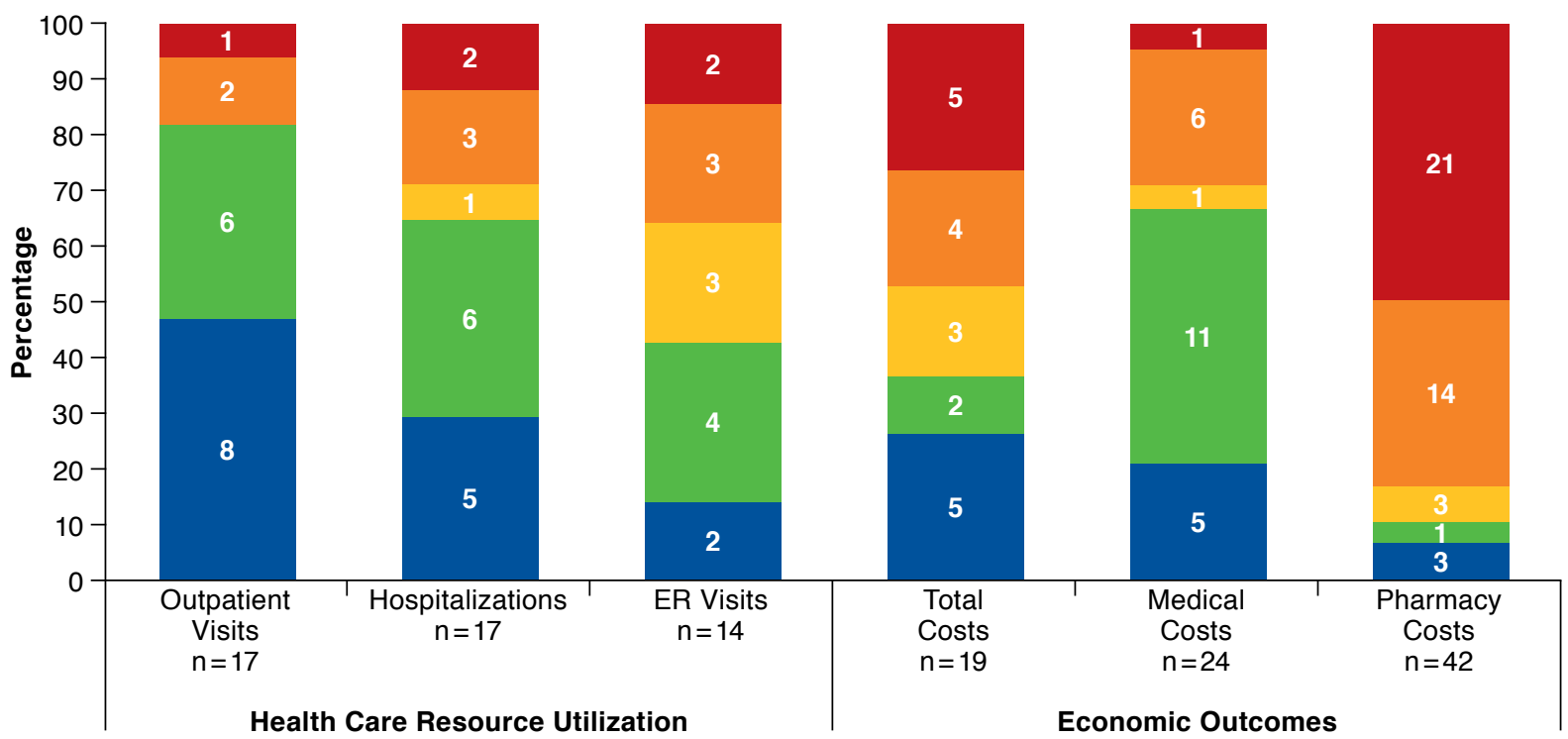

Negative (S) Negative (NS/U) Neutral $\quad$ Positive (NS/U) $\quad$ Positive (S)

$E R=$ emergency room; $N S=$ statistically not significant; $S=$ statistically significant; $U=$ unclear.

included total or medical costs (in addition to pharmacy costs) was evaluated to understand the overall effect of formulary restrictions. Of the 20 studies, only 4 showed reductions in pharmacy and total costs, whereas 10 studies showed reductions in pharmacy costs with negative medical and/or total costs $(n=9)$ or neutral total costs $(n=1)$, and 7 studies showed increases or no changes in pharmacy costs (Ben-Joseph et al. [2014] was counted twice because the results differed in commercial vs. Medicare populations $\left.{ }^{36}\right)$. Outcomes such as total costs and ER visits seemed to have almost equal distribution 
between positive and negative associations with formulary restrictions (Figure 3B).

Cost was the main reason for applying formulary restrictions in the majority of the included studies $(n=48)$, followed by multifactorial reasons (e.g., clinical/safety, $n=12$ ). The included studies assessed patients with a variety of indications, such as diabetic peripheral neuropathy/postherpetic neuralgia/ fibromyalgia/pain management $(n=12)$, schizophrenia/bipolar disorder $(n=9)$, anxiety/depression $(n=6)$, type 2 diabetes $(n=4)$, cancer $(n=3)$, allergic rhinitis/asthma $(n=2)$, and hypertension $(n=3)$, among others.

Plan types in the included studies were national or state Medicaid/Medicare $(n=28)$, commercial/employer $(n=21)$, Medicare/commercial $(n=2)$, and others $(n=9)$. Of all of the patient, health care resource utilization, and economic outcomes from studies assessing commercial/employer plans $(n=68)$, half were negatively associated with formulary restrictions $(n=34$, $50 \%)$, followed by positive ( $\mathrm{n}=29,42.6 \%)$ and neutral associations $(n=5,7.4 \%)$. Similarly, for outcomes in Medicaid plans $(n=52)$, the majority was negatively associated with formulary restrictions ( $n=28,53.8 \%)$, followed by positive $(n=19,36.6 \%)$ and neutral associations $(n=5,9.6 \%)$. However, for outcomes in Medicare plans $(n=27)$, the majority was positively associated with formulary restrictions $(n=14,51.9 \%)$, followed by negative $(n=9,33.3 \%)$ and neutral associations $(n=4,14.8 \%)$. Furthermore, drug utilization outcomes showed a similar trend within different managed care plans (commercial/employer: positive $92 \%$, negative $8 \%$; Medicare: positive $93 \%$, negative $7 \%$; and Medicaid: positive $88 \%$, negative $12 \%$ ).

\section{Discussion}

This SLR examined the association between formulary restrictions (specifically PA and ST) and a comprehensive list of patient and payer outcomes (medication adherence, clinical outcomes, treatment satisfaction, drug utilization, health care resource utilization, and economic outcomes) and captured their intended, as well as unintended, consequences. Our approach differed from that of previous reviews because we focused on PA and ST as the formulary restrictions, whereas previous reviews assessed cost sharing, ${ }^{14,15}$ tiered formulary and copayment, ${ }^{16}$ and multiple restrictions (ST, cost sharing, PA, PDLs, and quantity limits). ${ }^{26}$

In this SLR, a robust search strategy was used based on the Cochrane collaboration guide for SLRs, ${ }^{27}$ whereby multiple databases were queried, including MEDLINE, Embase, and Cochrane. Previous SLRs searched only the PubMed or Embase databases. ${ }^{14-16,26}$ Our focus was to identify recent studies (2005 onward) that looked at the effect of PA and ST because these are commonly used managed care policies that have not been systematically assessed in previous literature reviews for a wide range of patient and payer outcomes. Previous literature reviews have qualita- tively summarized the evidence on the effects of formulary restrictions; however, most reviews did not carry out any directional outcome-level analysis. ${ }^{14-17}$

Only 1 recent SLR (Happe et al. [2014]) reported aggregated directional effect of formulary restrictions on patient and payer outcomes (i.e., medication adherence, clinical outcomes, economic outcomes, or health care resource utilization). ${ }^{26}$ In the Happe et al. study, formulary restrictions were most frequently associated with negative outcomes (49.6\%), followed by neutral (36.3\%) and positive outcomes (14.1\%). ${ }^{26}$ Although we also found that formulary restrictions were most frequently associated with negative outcomes (50.6\%), we observed considerably more positive outcomes (40.2\%) and fewer neutral outcomes (9.1\%) compared with the Happe et al. study. In addition, Happe et al. found that medication adherence had the highest proportion of negative association with the formulary restrictions (68.3\%), followed by health care resource utilization (37.5\%), clinical outcomes (36.4\%), and economic outcomes (28.8\%). ${ }^{26}$ Our findings showed a similar proportion of studies with negative association between medication adherence and formulary restrictions (71\%) but much higher negative associations between formulary restrictions and clinical outcomes (92\%), health care resource utilization (64.5\%), and treatment satisfaction (100\%).

In agreement with the original intent, we found that formulary restrictions had a mostly positive effect on pharmacy costs. However, when the subset of studies that included total or medical costs (in addition to pharmacy costs) was evaluated, we observed that the majority of these studies showed either negative effect on total, medical, or pharmacy costs or no effect on pharmacy costs. These findings highlight the importance of evaluating more than just pharmacy costs to better understand the overall effect of formulary restrictions and hint at potential unintended consequences of formulary restrictions on payers. Moreover, we observed that results could depend on what type of payer (commercial vs. Medicare), disease state, or drug class is studied; thus, we suggest accounting for these variables when making formulary decisions.

\section{Limitations}

Certain limitations are inherent in nonrandomized studies and data, including accuracy and completeness of retrospective data, lack of control and selection, and inability to draw conclusions regarding cause and effect. The ability to draw conclusions from the reviewed studies may be impeded by differences in study design and variables included in each study. Some examples of variations observed in this literature review are study design (observational, time series, and cross-sectional); study method (difference in differences and regression); health insurance plan type (commercial, employer sponsored, Medicaid/Medicare, and TRICARE); cost type (total costs, medical costs, pharmacy 
costs, and disease-specific costs); disease state; medication class; and data source. Furthermore, the outcomes assessed were defined and measured in different ways across studies. For example, medication adherence could have been measured by proportion of days covered, medication possession ratio, or number of months in which a prescription was written. In addition, we only included studies that assessed the effect of placing formulary restrictions and did not include studies that assessed the effect of removing formulary restrictions.

Studies reporting drug utilization data along with patientrelated outcomes were included; however, studies reporting only pharmacy utilization data were not included as part of this SLR to maintain the scope of this review. Moreover, this systematic review focused on evaluating the effect of ST and PA and did not evaluate the effect of other formulary restrictions, such as cost sharing, PDLs, and quantity limits. Finally, this study was based on directional association of outcomes, as either positive or negative, which in some cases may be open to different interpretations (e.g., increased number of outpatient visits for chronic disease monitoring may be considered positive in some cases).

\section{Conclusions}

Findings from this SLR suggest that formulary coverage decisions by MCOs may lead to unintended consequences on patient or payer outcomes. Although formulary restrictions reduce drug utilization and associated drug costs, resulting in pharmacy cost savings, some of these cost savings may be offset by increased health care resource utilization and medical costs. Therefore, we recommend careful evaluation of formulary restriction policies before implementation and continued reevaluation while accounting for various disease states and plan types. Further research is warranted to evaluate the overall effect of formulary restrictions on patients, payers, and providers using medical and pharmacy data, in addition to understanding all related, including unseen, administrative costs.

\section{DISCLOSURES}

This study was funded by Novartis Pharmaceuticals. Park and Ko are employed by Novartis Pharmaceuticals in East Hanover, New Jersey, and Ko holds stock in Novartis. Raza, George, and Agrawal are employed by Novartis Healthcare in Hyderabad, India.

Study concept and design were contributed primarily by Park and Ko, along with the other authors. Raza, George, and Agrawal collected the data along with Park and Ko. Data interpretation was performed by Agrawal, Raza, George, Park, and Ko. The manuscript was written and revised by Raza, George, and Park, along with Ko and Agrawal.

Results from this systematic literature review were presented at the AMCP Annual Meeting 2016; San Francisco, California; April 19-22, 2016.

\section{REFERENCES}

1. Centers for Medicare $\&$ Medicaid Services. National health expenditures 2015 highlights. Available at: https://www.cms.gov/Research-Statistics-Dataand-Systems/Statistics-Trends-and-Reports/NationalHealthExpendData/ Downloads/highlights.pdf. Accessed June 28, 2017.

2. Buff MJ, Terrell TD. The role of third-party payers in medical cost increases. J Am Phys Surg. 2014;19(2):75-79.

3. Centers for Disease Control and Prevention. Table 95. Personal health care expenditures, by source of funds and type of expenditure: United States, selected years 1960-2014. In: National Center for Health Statistics. Health, United States, 2015: with special feature on racial and ethnic health disparities. 2016. Available at: http://www.cdc.gov/nchs/data/hus/2015/095. pdf. Accessed June 14, 2017.

4. Kongsvedt P. Essentials of Managed Health Care. 6th ed. Sudbury, MA: Jones and Bartlett Publishers; 2013.

5. Ridic G, Gleason S, Ridic O. Comparisons of health care systems in the United States, Germany and Canada. Mater Sociomed. 2012;24(2):112-20.

6. Carlton RI, Bramley TJ, Nightengale B, Conner TM, Zacker C. Review of outcomes associated with formulary restrictions: focus on step therapy. Am J Pharm Benefits. 2010;2(1):50-58.

7. McRae J, Vogenberg FR, Beaty SW, Mearns E, Varga S, Pizzi L. A review of U.S. drug costs relevant to Medicare, Medicaid, and commercial insurers post-Affordable Care Act enactment, 2010-2016. Pharmacoeconomics. 2017;35(2):215-23.

8. Blue Cross Blue Shield Blue Care Network of Michigan. Why do I need prior authorization for a prescription drug? Available at: http://www.bcbsm. com/index/health-insurance-help/faqs/plan-types/pharmacy/why-do-i-needprior-authorization-for-prescription-drug.html. Accessed June 14, 2017.

9. Blue Cross Blue Shield Blue Care Network of Michigan. What's step therapy and how does it work? Available at: http://www.bcbsm.com/medicare/ help/understanding-plans/pharmacy-prescription-drugs/step-therapy.html. Accessed June 14, 2017.

10. Starner CI, Fenrick B, Coleman J, Wickersham P, Gleason PP. Rosiglitazone prior authorization safety policy: a cohort study. J Manag Care Pharm. 2012;18(3):225-33. Available at: http://www.jmcp.org/doi/ abs/10.18553/jmcp.2012.18.3.225

11. Bazalo G, Weiss RC, Joshi AV. Impact of a prior authorization for pregabalin on health plan drug expenditures. Am J Manag Care. 2010;16 (5 Suppl):S154-59.

12. Huang X, Liu Z, Shankar RR, Rajpathak S. Description of anti-diabetic drug utilization pre- and post-formulary restriction of sitagliptin: findings from a national health plan. Curr Med Res Opin. 2015;31(8):1495-500.

13. Landsman PB, Yu W, Liu X, Teutsch SM, Berger ML. Impact of 3-tier pharmacy benefit design and increased consumer cost-sharing on drug utilization. Am J Manag Care. 2005;11(10):621-28.

14. Gibson T, Ozminkowski R, Goetzel R. The effects of prescription drug cost sharing: a review of the evidence. Am J Manag Care. 2005;11(11):730-40.

15. Goldman DP, Joyce GF, Zheng Y. Prescription drug cost sharing: associations with medication and medical utilization and spending and health. JAMA. 2007;298(1):61-69. 
16. Lu C, Ross-Degnan D, Soumerai S, Pearson S. Interventions designed to improve the quality and efficiency of medication use in managed care: a critical review of the literature-2001-2007. BMC Health Serv Res. 2008;8:75.

17. Shoemaker S, Pozniak A, Subramanian R, Mauch D. Effect of 6 managed care pharmacy tools: a review of the literature. J Manag Care Pharm. 2010;16(6 Suppl A):S3-20. Available at: http://www.jmcp.org/doi/ abs/10.18553/jmcp.2010.16.S6-A.1.

18. Motheral BR. Pharmaceutical step-therapy interventions: a critical review of the literature. J Manag Care Pharm. 2011;17(2):143-55. Available at: http://www.jmcp.org/doi/abs/10.18553/jmcp.2011.17.2.143.

19. Mark TL, Gibson TM, McGuigan K, Chu BC. The effects of antidepressant step therapy protocols on pharmaceutical and medical utilization and expenditures. Am J Psychiatry. 2010;167(10):1202-09.

20. Williams SA, Buysman EK, Hulbert EM, Bergeson JG, Zhang B, Graham J. Hemoglobin Alc outcomes and health care resource use in type 2 diabetes mellitus patients treated with combination oral antidiabetic drugs through step therapy and loose-dose and fixed-dose combinations. Manag Care. 2012;21(7):40-48.

21. Mark TL, Gibson TB, McGuigan KA. The effects of antihypertensive step-therapy protocols on pharmaceutical and medical utilization and expenditures. Am J Manag Care. 2009;15(2):123-31.

22. Starner CI, McClelland RS, Qiu Y, Zabinski RA, Cotter N, Gleason PP. A linezolid prior authorization program: clinical and economic outcomes. Am J Pharm Benefits. 2014;6(2):81-88.

23. Johnston SS, Sadosky A, Cappelleri JC, et al. Pregabalin prior authorization and potential medication-medication and medication-condition interactions. Am J Pharm Benefits. 2014;6(6):e185-92.

24. Clark RE, Baxter JD, Barton BA, Aweh G, O'Connell E, Fisher WH. The impact of prior authorization on buprenorphine dose, relapse rates, and cost for Massachusetts Medicaid beneficiaries with opioid dependence. Health Serv Res. 2014;49(6):1964-79.

25. Labiner DM, Drake KW. Formularies, costs, and quality of care: formulary restrictions are not the answer, especially for epilepsy. Neurol Clin Pract. 2013;3(1):71-74.

26. Happe LE, Clark D, Holliday E, Young T. A systematic literature review assessing the directional impact of managed care formulary restrictions on medication adherence, clinical outcomes, economic outcomes, and health care resource utilization. J Manag Care Spec Pharm. 2014;20(7):677-84. Available at: http://www.jmcp.org/doi/abs/10.18553/jmcp.2014.20.7.677.

27. The Cochrane Collaboration. Cochrane Handbook for Systematic Reviews of Interventions. Version 5.1.0. March 2011. Available at: http:// handbook.cochrane.org/. Accessed June 14, 2017.

28. Wells GA, Shea B, O'Connell D, et al. The Newcastle-Ottawa Scale (NOS) for assessing the quality of nonrandomised studies in meta-analyses. The Ottawa Hospital Research Institute. Available at: http://www.ohri.ca/ programs/clinical_epidemiology/oxford.asp. Accessed June 14, 2017.

29. Cochrane Effective Practice and Organisation of Care. EPOC resources for review authors. 2017. Available at: epoc.cochrane.org/epoc-resourcesreview-authors. Accessed June 28, 2017.

30. Critical Appraisal Skills Programme (CASP). 10 questions to help you make sense of qualitative research. Qualitative Research Checklist 31.05.13. Available at: http://media.wix.com/ugd/dded87_29c5b002d99342f788c6ac6 70e49f274.pdf. Accessed June 14, 2017.

31. Accurso AJ. The effect of a payer-mandated decrease in buprenorphine dose on relapse rates of patients with opioid dependence, a natural experiment. Presented at: SGIM 38th Annual Meeting; April 22-25, 2015; Toronto, ON, Canada. Available at: https://higherlogicdownload.s3.amazonaws.com/ SGIM/d307f134-78da-4fb8-beae-def2a3c048e5/UploadedImages/AM15\%20 docs/Oral\%20Presentations/Abstract\%20Session\%20I4.pdf. Accessed June 14, 2017.

32. Blomquist J. Generic first strategy in PPI class drives lowest net cost. J Manag Care Pharm. 2010;16(7):533 [Abstract]. Available at: http://www. jmcp.org/doi/pdf/10.18553/jmcp.2010.16.issue-7.
33. Bergeson JG, Worley K, Louder A, Ward M, Graham J. Retrospective database analysis of the impact of prior authorization for type 2 diabetes medications on health care costs in a Medicare advantage prescription drug plan population. J Manag Care Pharm. 2013;19(5):374-84. Available at: http:// www.jmcp.org/doi/10.18553/jmcp.2013.19.5.374.

34. Brown JD, Barrett A, Caffery E, Hourihan K, Ireys HT. Medication continuity among Medicaid beneficiaries with schizophrenia and bipolar disorder. Psychiatr Serv. 2013;64(9):878-85.

35. Delate T, Mager DE, Sheth J, Motheral BR. Clinical and financial outcomes associated with a proton pump inhibitor prior-authorization program in a Medicaid population. Am J Manag Care. 2005;11(1):29-36.

36. Ben-Joseph R, Chen CC, De AP, Wade RL, Shah D. Consequences of patient access restrictions to branded oxycodone hydrochloride extendedrelease tablets on healthcare utilization and costs in U.S. health plans. J Med Econ. 2014;17(10):708-18

37. Adams AS, Zhang F, LeCates RF, et al. Prior authorization for antidepressants in Medicaid: effects among disabled dual enrollees. Arch Intern Med. 2009;169(8):750-56.

38. Carroll NV, Smith JC, Berringer RA, Oestreich GL. Evaluation of an automated system for prior authorization: a COX-2 inhibitor example. Am J Manag Care. 2006;12(9):501-08.

39. Gleason PP, Williams C, Hrdy S, Hartwig SC, Lassen D. Medical and pharmacy expenditures after implementation of a cyclooxygenase-2 inhibitor prior authorization program. Pharmacotherapy. 2005;25(7):924-34.

40. Devine JW, Trice S, Allerman AA, Bacon TA. The effect of a prior authorization program for proton-pump inhibitors on medication persistence among the elderly. Value Health. 2009;12(3):A60 [Abstract PGI12]. Available at: http://www.valueinhealthjournal.com/article/S1098-3015(10)73359-3/ abstract. Accessed June 14, 2017.

41. Cotter ND. Promoting the ADA's diabetes type 2 treatment guidelines through pharmacy step-therapy programs. J Manag Care Pharm. 2011;17(7):568 [Abstract]. Available at: http://www.jmcp.org/doi/ pdf/10.18553/jmcp.2011.17.issue-7.

42. Farley JF, Cline RR, Schommer JC, Hadsall RS, Nyman JA. Retrospective assessment of Medicaid step-therapy prior authorization policy for atypical antipsychotic medications. Clin Ther. 2008;30(8):1524-39.

43. Erdman DR, LeBlanc L, Christiansen B, Gregory RS. Aromatase inhibitors utilization management opportunities: assessment of patient diagnoses, cost savings, and controlling off-label use. J Manag Care Pharm. 2010;16(2):142 [Abstract]. Available at: http://www.jmcp.org/doi/ pdf/10.18553/jmcp.2010.16.issue-2.

44. Dunn JD, Cannon E, Mitchell MP, Curtiss FR. Utilization and drug cost outcomes of a step-therapy edit for generic antidepressants in an HMO in an integrated health system. J Manag Care Pharm. 2006;12(4):294-302. Available at: http://www.jmcp.org/doi/abs/10.18553/jmcp.2006.12.4.294.

45. Harman M, Vogenberg FR. Employer perspectives on a specialty drug step-therapy program evaluation. Am Health Drug Benefits. 2016;9(6):319-21.

46. Hartung DM, Ketchum KL, Haxby DG. An evaluation of Oregon's evidence-based practitioner-managed prescription drug plan. Health Aff (Millwood). 2006;25(5):1423-32.

47. Goldman D, Fastenau J, Dirani R, et al. Medicaid prior authorization policies and imprisonment among patients with schizophrenia. Am J Manag Care. 2014;20(7):577-86.

48. Garcia MM, Angelini MC, Thomas T, Lenz K, Jeffrey P. Implementation of an opioid management initiative by a state Medicaid program. J Manag Care Spec Pharm. 2014;20(5):447-54. Available at: http://www.jmcp.org/ doi/10.18553/jmcp.2014.20.5.447.

49. Gleason PP, Phillips J, Fenrick BA, Delgado-Riley A, Starner CI. Dalfampridine prior authorization program: a cohort study. J Manag Care Pharm. 2013;19(1):18-25. Available at: http://www.jmcp.org/doi/ abs/10.18553/jmcp.2013.19.1.18. 
50. Hatoum HT, Lin S-J, Balu S. Impact of 5-hydroxytryptamine-3 receptor antagonist step therapy on severe chemotherapy-induced nausea and vomiting events in patients with lymphoma. Blood. 2011;118(21):3137 [Abstract 3137]. Available at: http://www.bloodjournal.org/content/118/21/3137?ssochecked=true. Accessed June 14, 2017.

51. Keast SL, Thompson D, Farmer K, Smith M, Nesser N, Harrison D. Impact of a prior authorization policy for montelukast on clinical outcomes for asthma and allergic rhinitis among children and adolescents in a state Medicaid program. J Manag Care Spec Pharm. 2014;20(6):612-21. Available at: http://www.jmcp.org/doi/abs/10.18553/jmcp.2014.20.6.612.

52. Herink M, Ketchum K, Tobias A, Carroll M. Evaluation of the oral anticoagulant prior authorization policy in the Oregon Medicaid program. Presented at: American College of Clinical Pharmacy Global Conference on Clinical Pharmacy; October 17-21, 2015; San Francisco, CA.

53. Johnston SS, Udall M, Alvir J, et al. Association between pregabalin access restrictions and pain-related health care utilization and expenditures in Medicare supplemental health plans. J Manag Care Pharm. 2012;18(7):542 [Abstract]. Available at: http://www.jmcp.org/doi/pdf/10.18553/ jmcp.2012.18.issue-7.

54. Lu CY, Adams AS, Ross-Degnan D, et al. Association between prior authorization for medications and health service use by Medicaid patients with bipolar disorder. Psychiatr Serv. 2011;62(2):186-93.

55. Lu CY, Law MR, Soumerai SB, et al. Impact of prior authorization on the use and costs of lipid-lowering medications among Michigan and Indiana dual enrollees in Medicaid and Medicare: results of a longitudinal, population-based study. Clin Ther. 2011;33(1):135-44.

56. LaPensee K, Carson R, Werner P, et al. Effect of equivalent and nonequivalent substitution of prescribed drugs for depression and anxiety disorders on patients' treatment adherence and perception. Value Health. 2010;13(3):A118 [Abstract PMH75]. Available at: http://www.valueinhealthjournal.com/article/S1098-3015(10)72570-5/abstract. Accessed June 14, 2017.

57. Louder AM, Joshi AV, Ball AT, Cappelleri JC, Deminski MC, Sanchez RJ. Impact of celecoxib restrictions in Medicare beneficiaries with arthritis. Am J Manag Care. 2011;17(7):503-12.

58. Lin SJ, Hatoum HT, Buchner D, Cox D, Balu S. Impact of 5-HT3 receptor antagonists on chemotherapy-induced nausea and vomiting: a retrospective cohort study. BMC Health Serv Res. 2012;12:215.

59. Law MR, Lu CY, Soumerai SB, et al. Impact of two Medicaid priorauthorization policies on antihypertensive use and costs among Michigan and Indiana residents dually enrolled in Medicaid and Medicare: results of a longitudinal, population-based study. Clin Ther. 2010;32(4):729-41.

60. Shen X, Stuart B, Powers C, Tom S, Magder L, Perfetto EM. How do formulary restrictions affect medication use and costs for low-income subsidy recipients in Medicare part d plans? Value Health. 2016;19(3):A261 [Abstract PHP17]. Available at: http://www.valueinhealthjournal.com/article/S10983015(16)00863-9/abstract. Accessed June 14, 2017.

61. Margolis JM, Johnston SS, Chu BC, et al. Effects of a Medicaid prior authorization policy for pregabalin. Am J Manag Care. 2009;15(10):e95-102.

62. Margolis JM, Cao Z, Onukwugha E, et al. Healthcare utilization and cost effects of prior authorization for pregabalin in commercial health plans. Am J Manag Care. 2010;16(6):447-56.

63. Risser JA, Vash PD, Nieto L. Does prior authorization of sibutramine improve medication compliance or weight loss? Obes Res. 2005;13(1):86-92. 64. Null KD, Moll K, Sadosky A, Pasquale MK, Cappelleri JC, Parsons B. Trends associated with implementing and lifting a pregabalin step therapy policy. Am J Pharm Benefits. 2016;8(2):e17-24.

65. Nau DP, Chi C, Mallya U, Kirking DM. Member satisfaction related to self-reported cost share and difficulty in obtaining prescription drugs in a university pharmacy benefit plan. J Manag Care Pharm. 2007;13(2):135-41. Available at: http://www.jmcp.org/doi/abs/10.18553/jmcp.2007.13.2.135.

66. Placzek HE, Masters ET, Gu T, et al. Prior authorization in the treatment of patients with pDPN and FM. Pain Pract. 2015;15(1):E9-19.
67. Seabury S, Lakdawalla DN, Walter D, et al. Medicaid formulary restrictions and expenditures for patients with major depressive disorder. Value Health. 2014;17(3):A222 [Abstract PMH78]. Available at: http://www.valueinhealthjournal.com/article/S1098-3015(14)01348-5/abstract. Accessed June 14, 2017.

68. Suehs BT, Louder A, Udall M, Cappelleri JC, Joshi AV, Patel NC. Impact of a pregabalin step therapy policy among Medicare advantage beneficiaries. Pain Pract. 2014;14(5):419-26.

69. Simeone JC, Marcoux RM, Quilliam BJ. Cost and utilization of behavioral health medications associated with rescission of an exemption for prior authorization for severe and persistent mental illness in the Vermont Medicaid program. J Manag Care Pharm. 2010;16(5):317-28. Available at: http://www.jmcp.org/doi/abs/10.18553/jmcp.2010.16.5.317.

70. Siracuse MV, Vuchetich PJ. Impact of Medicaid prior authorization requirement for COX-2 inhibitor drugs in Nebraska. Health Serv Res. 2008;43(1 Pt 2):435-50.

71. Soumerai SB, Zhang F, Ross-Degnan D, et al. Use of atypical antipsychotic drugs for schizophrenia in Maine Medicaid following a policy change. Health Aff (Millwood). 2008;27(3):wl85-95.

72. Suehs BT, Sikirica V, Mudumby P, Dufour R, Patel NC. Impact of a step therapy for guanfacine extended-release on medication utilization and health care expenditures among individuals receiving treatment for ADHD J Manag Care Spec Pharm. 2015;21(9):793-802, 802a-i. Available at: http:// www.jmcp.org/doi/10.18553/jmcp.2015.21.9.793.

73. Tunis SL, Faries DE, Nyhuis AW, Kinon BJ, Ascher-Svanum H, Aquila R. Cost-effectiveness of olanzapine as first-line treatment for schizophrenia: results from a randomized, open-label, 1-year trial. Value Health. 2006;9(2):77-89.

74. Sun SX, Jing Y, Aruru M, Lee KY. Economic evaluation of a prior authorization program for biologic response modifiers. Drug Benefit Trends. 2008;20:26-31.

75. Sun SX, Jing Y, Lee KY, McMurray J, Young E. Impact of formulary management and step therapy for non-sedating antihistamines on prescription drug utilisation and costs. J Med Econ. 2007;10(4):367-78.

76. West JC, Wilk JE, Rae DS, et al. First-year Medicare part D prescription drug benefits: medication access and continuity among dual eligible psychiatric patients. J Clin Psychiatry. 2010;71(4):400-10.

77. Yokoyama K, Yang W, Preblick R, Frech-Tamas F. Effects of a step-therapy program for angiotensin receptor blockers on antihypertensive medication utilization patterns and cost of drug therapy. J Manag Care Pharm. 2007;13(3):235-44. Available at: http://www.jmcp.org/doi/abs/10.18553/ jmcp.2007.13.3.235.

78. Zhang Y, Adams AS, Ross-Degnan D, Zhang F, Soumerai SB. Effects of prior authorization on medication discontinuation among Medicaid beneficiaries with bipolar disorder. Psychiatr Serv. 2009;60(4):520-57.

79. Walthour A, Seymour L, Tackett R, Perri M. Assessment of changes in utilization of health-care services after implementation of a prior authorization policy for atypical antipsychotic agents. Ann Pharmacother. 2010;44(5):809-18.

80. Udall M, Louder A, Suehs BT, Cappelleri JC, Joshi AV, Patel NC. Impact of a step-therapy protocol for pregabalin on healthcare utilization and expenditures in a commercial population. J Med Econ. 2013;16(6):784-92.

81. Zhang Z, Jannsen X, Rogers N, Shetty S, Etemad L. Impact of generic step therapy of divalproex ER, levetiracetam, lamotrigine, and topiramate on health care utilization in epilepsy patients. J Manag Care Pharm. 2012;18(2):183 [Abstract]. Available at: http://www.jmcp.org/doi/ pdf/10.18553/jmcp.2012.18.issue-2.

82. Whiteley J, Landsman-Blumberg PB, Cao Z, Alvir J, Harnett J. Effects of a desvenlafaxine prior authorization on health care resource utilization and costs in commercially insured patients. J Manag Care Pharm. 2011;17(7):557 [Abstract]. Available at: http://www.jmcp.org/doi/pdf/10.18553/jmcp.2011.17.issue-7. 


\section{APPENDIX A Study Characteristics}

\begin{tabular}{|c|c|c|c|c|c|c|}
\hline Reference & $\begin{array}{l}\text { Restriction } \\
\text { Type }\end{array}$ & Indication & Study Design & $\begin{array}{l}\text { Outcome } \\
\text { Type }\end{array}$ & Outcome & $\begin{array}{l}\text { Direction of } \\
\text { Association }\end{array}$ \\
\hline \multirow[t]{2}{*}{$\begin{array}{l}\text { Margolis et al. } \\
2010^{62}\end{array}$} & \multirow[t]{2}{*}{$\mathrm{PA}$} & \multirow{2}{*}{$\begin{array}{l}\text { Painful diabetic peripheral } \\
\text { neuropathy or postherpetic } \\
\text { neuralgia }\end{array}$} & \multirow[t]{2}{*}{$\begin{array}{l}\text { Retrospective } \\
\text { observational }\end{array}$} & Economic & $\begin{array}{l}\text { 1. Total costs } \\
\text { 2. Pharmacy costs }\end{array}$ & $\begin{array}{l}\text { 1. Positive (NS) } \\
\text { 2. Positive (NS) }\end{array}$ \\
\hline & & & & Utilization & 1. Drug utilization & 1. Positive (S) \\
\hline \multirow[t]{2}{*}{$\begin{array}{l}\text { Margolis et al. } \\
200961\end{array}$} & \multirow[t]{2}{*}{$\mathrm{PA}$} & \multirow[t]{2}{*}{$\begin{array}{l}\text { Diabetic peripheral neuropathy or } \\
\text { postherpetic neuralgia }\end{array}$} & \multirow[t]{2}{*}{$\begin{array}{l}\text { Retrospective } \\
\text { observational }\end{array}$} & Economic & $\begin{array}{l}\text { 1. Total costs } \\
\text { 2. Pharmacy costs }\end{array}$ & $\begin{array}{l}\text { 1. Negative }(S) \\
\text { 2. Positive }(S)\end{array}$ \\
\hline & & & & Utilization & 1. Drug utilization & 1. Positive (S) \\
\hline $\begin{array}{l}\text { Devine et al. } \\
2009^{40}\end{array}$ & PA & Gastrointestinal-related diagnoses & $\begin{array}{l}\text { Retrospective } \\
\text { observational }\end{array}$ & Adherence & 1. Medication adherence & 1. Negative (S) \\
\hline \multirow{2}{*}{$\begin{array}{l}\text { Sun et al. } \\
2008^{74}\end{array}$} & \multirow[t]{2}{*}{ PA } & \multirow{2}{*}{$\begin{array}{l}\text { Rheumatoid arthritis, juvenile } \\
\text { rheumatoid arthritis, Crohn } \\
\text { disease, ankylosing spondylitis, } \\
\text { psoriatic arthritis, psoriasis, and } \\
\text { other spondyloarthropathies }\end{array}$} & \multirow{2}{*}{$\begin{array}{l}\text { Retrospective } \\
\text { case control }\end{array}$} & Economic & 1. Pharmacy costs & 1. Positive (NS) \\
\hline & & & & Utilization & 1. Drug utilization & 1. Positive (NS) \\
\hline \multirow{2}{*}{$\begin{array}{l}\text { Johnston et al. } \\
201423\end{array}$} & \multirow[t]{2}{*}{ PA } & \multirow{2}{*}{$\begin{array}{l}\text { Painful diabetic peripheral } \\
\text { neuropathy or fibromyalgia }\end{array}$} & \multirow{2}{*}{$\begin{array}{l}\text { Retrospective } \\
\text { observational }\end{array}$} & Clinical & 1. Clinical outcomes & 1. Negative (S) \\
\hline & & & & Utilization & 1. Drug utilization & 1. Positive (S) \\
\hline \multirow{3}{*}{$\begin{array}{l}\text { Simeone et al. } \\
2010^{69}\end{array}$} & \multirow[t]{3}{*}{$\mathrm{PA}$} & \multirow[t]{3}{*}{ Multiple indications } & \multirow{3}{*}{$\begin{array}{l}\text { Retrospective } \\
\text { observational }\end{array}$} & Economic & 1. Pharmacy costs & 1. Positive (S) \\
\hline & & & & HCRU & 1. Hospitalizations & 1. Positive (S) \\
\hline & & & & Utilization & 1. Drug utilization & 1. Negative (S) \\
\hline \multirow{4}{*}{$\begin{array}{l}\text { Risser et al. } \\
2005^{63}\end{array}$} & \multirow[t]{4}{*}{$\mathrm{PA}$} & \multirow[t]{4}{*}{ Weight loss } & \multirow{4}{*}{$\begin{array}{l}\text { Retrospective } \\
\text { observational }\end{array}$} & Adherence & 1. Medication adherence & 1. Positive (S) \\
\hline & & & & Clinical & 1. Clinical outcomes & 1. Positive (NS) \\
\hline & & & & HCRU & 1. Outpatient visits & 1. Negative $(\mathrm{S})$ \\
\hline & & & & Utilization & 1. Drug utilization & 1. Negative (S) \\
\hline \multirow{2}{*}{$\begin{array}{l}\text { Carroll et al. } \\
2006^{38}\end{array}$} & \multirow[t]{2}{*}{ PA } & \multirow[t]{2}{*}{ Gastrointestinal related or pain } & Retrospective & Economic & 1. Pharmacy costs & 1. Positive (S) \\
\hline & & & observational & Utilization & 1. Drug utilization & 1. Positive (S) \\
\hline $\begin{array}{l}\text { Accurso } \\
2015^{31} \\
\end{array}$ & $\mathrm{PA}$ & Opioid dependence & $\begin{array}{l}\text { Retrospective } \\
\text { observational }\end{array}$ & Clinical & 1. Clinical outcomes & 1. Negative (S) \\
\hline Garcia et al. & $\mathrm{PA}$ & Pain management & Retrospective & Economic & 1. Pharmacy costs & 1. Positive (S) \\
\hline 201448 & & & observational & Utilization & 1. Drug utilization & 1. Positive (S) \\
\hline Placzek et al. & $\mathrm{PA}$ & Painful diabetic peripheral & Retrospective & Adherence & 1. Medication adherence & 1. Neutral \\
\hline $2015^{66}$ & & neuropathy or fibromyalgia & observational & Economic & $\begin{array}{l}\text { 1. Total costs } \\
\text { 2. Medical costs } \\
\text { 3. Pharmacy costs }\end{array}$ & $\begin{array}{l}\text { 1. Negative (NS) } \\
\text { 2. Negative (NS) } \\
\text { 3. Neutral }\end{array}$ \\
\hline & & & & Utilization & 1. Drug utilization & 1. Positive (NS) \\
\hline $\begin{array}{l}\text { Goldman et al. } \\
201447\end{array}$ & PA & Schizophrenia & $\begin{array}{l}\text { Retrospective } \\
\text { observational }\end{array}$ & Clinical & 1. Clinical outcomes & 1. Negative (S) \\
\hline $\begin{array}{l}\text { Starner et al. } \\
2014^{22}\end{array}$ & $\mathrm{PA}$ & $\begin{array}{l}\text { Bacterial pneumonia, skin and } \\
\text { skin structure infections, and } \\
\text { vancomycin-resistant enterococcal }\end{array}$ & $\begin{array}{l}\text { Retrospective } \\
\text { observational }\end{array}$ & Economic & $\begin{array}{l}\text { 1. Total costs } \\
\text { 2. Medical costs } \\
\text { 3. Pharmacy costs }\end{array}$ & $\begin{array}{l}\text { 1. Positive (S) } \\
\text { 2. Positive (NS) } \\
\text { 3. Positive (S) } \\
\end{array}$ \\
\hline & & infections & & HCRU & $\begin{array}{l}\text { 1. Outpatient visits } \\
\text { 2. Hospitalizations } \\
\text { 3. Emergency room visits }\end{array}$ & $\begin{array}{l}\text { 1. Negative (NS) } \\
\text { 2. Positive (NS) } \\
\text { 3. Negative (NS) }\end{array}$ \\
\hline & & & & Utilization & 1. Drug utilization & 1. Positive (S) \\
\hline Gleason et al. & PA & Multiple sclerosis & Retrospective & Economic & 1. Pharmacy costs & 1. Positive (U) \\
\hline $2013^{49}$ & & & observational & Utilization & 1. Drug utilization & 1. Positive (S) \\
\hline $\begin{array}{l}\text { Whiteley et al. } \\
2011^{82}\end{array}$ & PA & Major depressive disorder & $\begin{array}{l}\text { Retrospective } \\
\text { observational }\end{array}$ & HCRU & $\begin{array}{l}\text { 1. Outpatient visits } \\
\text { 2. Hospitalizations }\end{array}$ & $\begin{array}{l}\text { 1. Negative }(S) \\
\text { 2. Negative }(S)\end{array}$ \\
\hline & & & & Utilization & 1. Drug utilization & 1. Positive (S) \\
\hline Starner et al. & PA & Type 2 diabetes & Retrospective & Economic & 1. Pharmacy costs & 1. Positive (U) \\
\hline $2012^{10}$ & & & observational & Utilization & 1. Prescription & 1. Positive (S) \\
\hline Law et al. & PA & Hypertension & Time-series & Economic & 1. Pharmacy costs & 1. Positive (S) \\
\hline $2010^{59}$ & & & analysis & Utilization & 1. Drug utilization & 1. Positive (S) \\
\hline
\end{tabular}

continued on next page 


\section{APPENDIX A Study Characteristics (continued)}

\begin{tabular}{|c|c|c|c|c|c|c|}
\hline Reference & $\begin{array}{l}\text { Restriction } \\
\text { Type }\end{array}$ & Indication & Study Design & $\begin{array}{l}\text { Outcome } \\
\text { Type }\end{array}$ & Outcome & $\begin{array}{l}\text { Direction of } \\
\text { Association }\end{array}$ \\
\hline $\begin{array}{l}\text { Walthour et al. } \\
2010^{79}\end{array}$ & PA & Schizophrenia & $\begin{array}{l}\text { Retrospective } \\
\text { observational }\end{array}$ & HCRU & $\begin{array}{l}\text { 1. Outpatient visits } \\
\text { 2. Hospitalizations } \\
\text { 3. Emergency room visits }\end{array}$ & $\begin{array}{l}\text { 1. Positive (NS) } \\
\text { 2. Positive (S) } \\
\text { 3. Positive (S) }\end{array}$ \\
\hline $\begin{array}{l}\text { Erdman et al. } \\
2010^{43}\end{array}$ & PA & Breast cancer & $\begin{array}{l}\text { Retrospective } \\
\text { observational }\end{array}$ & Economic & 1. Pharmacy costs & 1. Positive (U) \\
\hline \multirow{2}{*}{$\begin{array}{l}\text { Siracuse et al. } \\
2008^{70}\end{array}$} & \multirow[t]{2}{*}{$\mathrm{PA}$} & \multirow[t]{2}{*}{ Pain management } & \multirow{2}{*}{$\begin{array}{l}\text { Retrospective } \\
\text { observational }\end{array}$} & Economic & 1. Pharmacy costs & 1. Positive (U) \\
\hline & & & & Utilization & 1. Drug utilization & 1. Positive (S) \\
\hline $\begin{array}{l}\text { Hartung et al. } \\
2006^{46}\end{array}$ & $\mathrm{PA}$ & Multiple diseases & $\begin{array}{l}\text { Retrospective } \\
\text { observational } \\
\end{array}$ & Economic & 1. Pharmacy costs & 1. Positive (S) \\
\hline \multirow{2}{*}{$\begin{array}{l}\mathrm{Lu} \\
2011^{55}\end{array}$} & \multirow[t]{2}{*}{ PA } & \multirow[t]{2}{*}{ Hyperlipidemia } & \multirow{2}{*}{$\begin{array}{l}\text { Time-series } \\
\text { analysis }\end{array}$} & Economic & 1. Pharmacy costs & 1. Positive (NS) \\
\hline & & & & Utilization & 1. Drug utilization & 1. Positive (NS) \\
\hline \multirow{2}{*}{$\begin{array}{l}\mathrm{Lu} \\
2011^{54}\end{array}$} & \multirow[t]{2}{*}{$\mathrm{PA}$} & \multirow[t]{2}{*}{ Bipolar disorder } & \multirow{2}{*}{$\begin{array}{l}\text { Retrospective } \\
\text { observational }\end{array}$} & Adherence & 1. Medication adherence & 1. Negative (S) \\
\hline & & & & HCRU & $\begin{array}{l}\text { 1. Outpatient visits } \\
\text { 2. Hospitalizations } \\
\text { 3. Emergency room visits }\end{array}$ & $\begin{array}{l}\text { 1. Negative (NS) } \\
\text { 2. Negative (NS) } \\
\text { 3. Positive (NS) }\end{array}$ \\
\hline \multirow[t]{2}{*}{$\begin{array}{l}\text { Seabury et al. } \\
201467, a\end{array}$} & \multirow[t]{2}{*}{$\mathrm{PA}$} & \multirow[t]{2}{*}{ Major depressive disorder } & \multirow[t]{2}{*}{$\begin{array}{l}\text { Retrospective } \\
\text { observational }\end{array}$} & Economic & $\begin{array}{l}\text { 1. Total costs } \\
\text { 2. Medical costs } \\
\text { 3. Pharmacy costs }\end{array}$ & $\begin{array}{l}\text { 1. Neutral } \\
\text { 2. Negative (NS) } \\
\text { 3. Neutral }\end{array}$ \\
\hline & & & & HCRU & 1. Hospitalizations & 1. Negative (S) \\
\hline \multirow[t]{2}{*}{$\begin{array}{l}\text { Keast et al. } \\
201451\end{array}$} & \multirow[t]{2}{*}{$\mathrm{PA}$} & \multirow[t]{2}{*}{ Allergic rhinitis, asthma, or both } & \multirow[t]{2}{*}{$\begin{array}{l}\text { Retrospective } \\
\text { observational }\end{array}$} & HCRU & $\begin{array}{l}\text { 1. Outpatient visits } \\
\text { 2. Emergency room visits }\end{array}$ & $\begin{array}{l}\text { 1. Positive (S) } \\
\text { 2. Positive (S) }\end{array}$ \\
\hline & & & & Utilization & 1. Drug utilization & 1. Positive (S) \\
\hline \multirow[t]{3}{*}{$\begin{array}{l}\text { Delate et al. } \\
2005^{35}\end{array}$} & \multirow[t]{3}{*}{$\mathrm{PA}$} & \multirow[t]{3}{*}{ Gastrointestinal-related diagnoses } & \multirow[t]{3}{*}{$\begin{array}{l}\text { Time-series } \\
\text { analysis }\end{array}$} & Economic & $\begin{array}{l}\text { 1. Medical costs } \\
\text { 2. Pharmacy costs }\end{array}$ & $\begin{array}{l}\text { 1. Negative }(\mathrm{U}) \\
\text { 2. Positive }(\mathrm{S})\end{array}$ \\
\hline & & & & HCRU & $\begin{array}{l}\text { 1. Outpatient visits } \\
\text { 2. Hospitalizations } \\
\text { 3. Emergency room visits }\end{array}$ & $\begin{array}{l}\text { 1. Negative }(S) \\
\text { 2. Negative }(S) \\
\text { 3. Negative }(S)\end{array}$ \\
\hline & & & & Utilization & 1. Drug utilization & 1. Positive (S) \\
\hline \multirow{4}{*}{$\begin{array}{l}\text { Clark et al. } \\
201424\end{array}$} & \multirow[t]{4}{*}{ PA } & \multirow[t]{4}{*}{ Opioid dependence } & \multirow{4}{*}{$\begin{array}{l}\text { Retrospective } \\
\text { observational }\end{array}$} & Adherence & 1. Medication adherence & 1. Negative (NS) \\
\hline & & & & Clinical & 1. Clinical outcomes & 1. Negative (S) \\
\hline & & & & Economic & $\begin{array}{l}\text { 1. Total costs } \\
\text { 2. Pharmacy costs }\end{array}$ & $\begin{array}{l}\text { 1. Negative }(S) \\
\text { 2. Positive }(S)\end{array}$ \\
\hline & & & & Utilization & 1. Drug utilization & 1. Positive (NS) \\
\hline \multirow{3}{*}{$\begin{array}{l}\text { Adams et al. } \\
2009^{37}\end{array}$} & PA & Depression & Retrospective & Adherence & 1. Medication adherence & 1. Negative (NS) \\
\hline & & & observational & HCRU & $\begin{array}{l}\text { 1. Hospitalizations } \\
\text { 2. Emergency room visits }\end{array}$ & $\begin{array}{l}\text { 1. Negative (NS) } \\
\text { 2. Neutral }\end{array}$ \\
\hline & & & & Utilization & 1. Drug utilization & 1. Positive (S) \\
\hline Zhang et al. & $\mathrm{PA}$ & Bipolar disorder & Retrospective & Adherence & 1. Medication adherence & 1. Negative $(\mathrm{S})$ \\
\hline $2009^{78}$ & & & observational & Economic & 1. Pharmacy costs & 1. Positive (U) \\
\hline & & & & Utilization & 1. Drug utilization & 1. Positive (S) \\
\hline $\begin{array}{l}\text { Gleason et al. } \\
2005^{39}\end{array}$ & $\mathrm{PA}$ & Inflammation/pain management & $\begin{array}{l}\text { Retrospective } \\
\text { observational }\end{array}$ & Economic & $\begin{array}{l}\text { 1. Medical costs } \\
\text { 2. Pharmacy costs }\end{array}$ & $\begin{array}{l}\text { 1. Negative }(S) \\
\text { 2. Positive }(S)\end{array}$ \\
\hline & & & & HCRU & $\begin{array}{l}\text { 1. Outpatient visits } \\
\text { 2. Hospitalizations } \\
\text { 3. Emergency room visits }\end{array}$ & $\begin{array}{l}\text { 1. Positive (NS) } \\
\text { 2. Negative (NS) } \\
\text { 3. Negative (NS) }\end{array}$ \\
\hline & & & & Utilization & 1. Drug utilization & 1. Positive (S) \\
\hline Soumerai et al. & PA & Schizophrenia & Retrospective & Adherence & 1. Medication adherence & 1. Negative (NS) \\
\hline $2008^{71}$ & & & observational & Economic & 1. Pharmacy costs & 1. Positive (S) \\
\hline & & & & Utilization & 1. Drug utilization & 1. Positive (NS) \\
\hline
\end{tabular}




\section{APPENDIX A Study Characteristics (continued)}

\begin{tabular}{|c|c|c|c|c|c|c|}
\hline Reference & $\begin{array}{l}\text { Restriction } \\
\text { Type }\end{array}$ & Indication & Study Design & $\begin{array}{l}\text { Outcome } \\
\text { Type }\end{array}$ & Outcome & $\begin{array}{l}\text { Direction of } \\
\text { Association }\end{array}$ \\
\hline \multirow[t]{6}{*}{$\begin{array}{l}\text { Ben-Joseph et al. } \\
201436\end{array}$} & \multirow[t]{3}{*}{$\begin{array}{c}\text { PA } \\
\text { (Commercial) }\end{array}$} & \multirow[t]{3}{*}{ Pain management } & \multirow[t]{6}{*}{$\begin{array}{l}\text { Retrospective } \\
\text { observational }\end{array}$} & Economic & $\begin{array}{l}\text { 1. Total costs } \\
\text { 2. Medical costs } \\
\text { 3. Pharmacy costs }\end{array}$ & $\begin{array}{l}\text { 1. Negative }(S) \\
\text { 2. Negative }(S) \\
\text { 3. Negative }(S)\end{array}$ \\
\hline & & & & HCRU & 1. Outpatient visits & 1. Negative (S) \\
\hline & & & & Utilization & 1. Drug utilization & 1. Positive (NS) \\
\hline & \multirow[t]{3}{*}{$\begin{array}{c}\text { PA } \\
\text { (Medicare) }\end{array}$} & \multirow[t]{3}{*}{ Pain management } & & Economic & $\begin{array}{l}\text { 1. Total costs } \\
\text { 2. Medical costs } \\
\text { 3. Pharmacy costs }\end{array}$ & $\begin{array}{l}\text { 1. Negative }(\mathrm{S}) \\
\text { 2. Negative }(\mathrm{S}) \\
\text { 3. Positive (NS) }\end{array}$ \\
\hline & & & & HCRU & 1. Outpatient visits & 1. Negative (S) \\
\hline & & & & Utilization & 1. Drug utilization & 1. Positive (NS) \\
\hline $\begin{array}{l}\text { Brown et al. } \\
2013^{34}\end{array}$ & $\mathrm{PA}$ & $\begin{array}{l}\text { Schizophrenia and bipolar } \\
\text { disorder }\end{array}$ & $\begin{array}{l}\text { Retrospective } \\
\text { observational }\end{array}$ & Adherence & 1. Medication adherence & 1. Negative (S) \\
\hline \multirow{2}{*}{$\begin{array}{l}\text { Herink et al. } \\
2015^{52}\end{array}$} & \multirow[t]{2}{*}{$\mathrm{PA}$} & \multirow{2}{*}{$\begin{array}{l}\text { Patients with a claim for } \\
\text { anticoagulants }\end{array}$} & \multirow{2}{*}{$\begin{array}{l}\text { Retrospective } \\
\text { observational }\end{array}$} & Clinical & 1. Clinical outcomes & 1. Negative (U) \\
\hline & & & & Utilization & 1. Drug utilization & 1. Positive (U) \\
\hline \multicolumn{7}{|l|}{ Step Therapy } \\
\hline \multirow{4}{*}{$\begin{array}{l}\text { Mark et al. } \\
2010^{19}\end{array}$} & \multirow[t]{4}{*}{ ST } & \multirow[t]{4}{*}{ Depression } & \multirow{4}{*}{$\begin{array}{l}\text { Retrospective } \\
\text { observational }\end{array}$} & Adherence & 1. Medication adherence & 1. Neutral \\
\hline & & & & Economic & $\begin{array}{l}\text { 1. Medical costs } \\
\text { 2. Pharmacy costs }\end{array}$ & $\begin{array}{l}\text { 1. Negative }(\mathrm{U}) \\
\text { 2. Positive }(\mathrm{S})\end{array}$ \\
\hline & & & & HCRU & $\begin{array}{l}\text { 1. Outpatient visits } \\
\text { 2. Hospitalizations } \\
\text { 3. Emergency room visits }\end{array}$ & $\begin{array}{l}\text { 1. Negative }(S) \\
\text { 2. Negative }(S) \\
\text { 3. Negative }(S)\end{array}$ \\
\hline & & & & Utilization & 1. Drug utilization & 1. Positive (NS) \\
\hline \multirow{4}{*}{$\begin{array}{l}\text { Mark et al. } \\
2009^{21}\end{array}$} & \multirow[t]{4}{*}{ ST } & \multirow[t]{4}{*}{ Hypertension } & \multirow{4}{*}{$\begin{array}{l}\text { Retrospective } \\
\text { observational }\end{array}$} & Adherence & 1. Medication adherence & 1. Negative (S) \\
\hline & & & & Economic & $\begin{array}{l}\text { 1. Total costs } \\
\text { 2. Medical costs } \\
\text { 3. Pharmacy costs }\end{array}$ & $\begin{array}{l}\text { 1. Positive (S) } \\
\text { 2. Negative (NS) } \\
\text { 3. Positive (S) }\end{array}$ \\
\hline & & & & HCRU & $\begin{array}{l}\text { 1. Outpatient visits } \\
\text { 2. Hospitalizations } \\
\text { 3. Emergency room visits }\end{array}$ & $\begin{array}{l}\text { 1. Negative (S) } \\
\text { 2. Negative (S) } \\
\text { 3. Positive (NS) }\end{array}$ \\
\hline & & & & Utilization & 1. Drug utilization & 1. Positive (S) \\
\hline \multirow{2}{*}{$\begin{array}{l}\text { Sun et al. } \\
2007^{75}\end{array}$} & \multirow[t]{2}{*}{ ST } & \multirow[t]{2}{*}{ Allergic rhinitis } & \multirow{2}{*}{$\begin{array}{l}\text { Retrospective } \\
\text { observational }\end{array}$} & Economic & 1. Total costs & 1. Positive (S) \\
\hline & & & & Utilization & 1. Drug utilization & 1. Positive (S) \\
\hline $\begin{array}{l}\text { Yokoyama et al. } \\
2007^{77}\end{array}$ & ST & Hypertension & $\begin{array}{l}\text { Retrospective } \\
\text { observational }\end{array}$ & Economic & 1. Pharmacy costs & 1. Positive (S) \\
\hline \multirow{2}{*}{$\begin{array}{l}\text { Dunn et al. } \\
2006^{44}\end{array}$} & \multirow[t]{2}{*}{ ST } & \multirow[t]{2}{*}{ Depression } & \multirow{2}{*}{$\begin{array}{l}\text { Retrospective } \\
\text { observational }\end{array}$} & Economic & 1. Pharmacy costs & 1. Positive (S) \\
\hline & & & & Utilization & 1. Drug utilization & 1. Positive (S) \\
\hline $\begin{array}{l}\text { Hatoum et al. } \\
2011^{50}\end{array}$ & ST & Lymphoma & $\begin{array}{l}\text { Retrospective } \\
\text { observational }\end{array}$ & Clinical & 1. Clinical outcomes & 1. Negative (S) \\
\hline \multirow{3}{*}{$\begin{array}{l}\text { Williams et al. } \\
2012^{20}\end{array}$} & \multirow[t]{3}{*}{ ST } & \multirow[t]{3}{*}{ Type 2 diabetes } & Retrospective & Clinical & 1. Clinical outcomes & 1. Negative (S) \\
\hline & & & & Economic & $\begin{array}{l}\text { 1. Total costs } \\
\text { 2. Medical costs } \\
\text { 3. Pharmacy costs }\end{array}$ & $\begin{array}{l}\text { 1. Negative }(\mathrm{U}) \\
\text { 2. Negative }(\mathrm{U}) \\
\text { 3. Negative (U) }\end{array}$ \\
\hline & & & & HCRU & $\begin{array}{l}\text { 1. Outpatient visits } \\
\text { 2. Hospitalizations } \\
\text { 3. Emergency room visits }\end{array}$ & $\begin{array}{l}\text { 1. Negative (U) } \\
\text { 2. Negative (U) } \\
\text { 3. Negative (U) }\end{array}$ \\
\hline $\begin{array}{l}\text { Udall et al. } \\
2013^{80}\end{array}$ & ST & $\begin{array}{l}\text { Painful diabetic peripheral } \\
\text { neuropathy, postherpetic } \\
\text { neuralgia, or fibromyalgia }\end{array}$ & $\begin{array}{l}\text { Retrospective } \\
\text { observational }\end{array}$ & Economic & $\begin{array}{l}\text { 1. Total costs } \\
\text { 2. Medical costs } \\
\text { 3. Pharmacy costs }\end{array}$ & $\begin{array}{l}\text { 1. Negative (S) } \\
\text { 2. Negative (NS) } \\
\text { 3. Positive (NS) } \\
\end{array}$ \\
\hline & & & & HCRU & $\begin{array}{l}\text { 1. Outpatient visits } \\
\text { 2. Hospitalizations } \\
\text { 3. Emergency room visits }\end{array}$ & $\begin{array}{l}\text { 1. Negative (S) } \\
\text { 2. Positive (NS) } \\
\text { 3. Negative (NS) }\end{array}$ \\
\hline & & & & Utilization & 1. Drug utilization & 1. Positive (NS) \\
\hline
\end{tabular}




\section{APPENDIX A Study Characteristics (continued)}

\begin{tabular}{|c|c|c|c|c|c|c|}
\hline Reference & $\begin{array}{l}\text { Restriction } \\
\text { Type }\end{array}$ & Indication & Study Design & $\begin{array}{l}\text { Outcome } \\
\text { Type }\end{array}$ & Outcome & $\begin{array}{l}\text { Direction of } \\
\text { Association }\end{array}$ \\
\hline \multirow[t]{3}{*}{$\begin{array}{l}\text { Suehs et al. } \\
201468\end{array}$} & \multirow[t]{3}{*}{ ST } & \multirow[t]{3}{*}{$\begin{array}{l}\text { Painful diabetic peripheral } \\
\text { neuropathy, postherpetic } \\
\text { neuralgia, or fibromyalgia }\end{array}$} & \multirow[t]{3}{*}{$\begin{array}{l}\text { Retrospective } \\
\text { observational }\end{array}$} & Economic & $\begin{array}{l}\text { 1. Total costs } \\
\text { 2. Medical costs } \\
\text { 3. Pharmacy costs }\end{array}$ & $\begin{array}{l}\text { 1. Positive (NS) } \\
\text { 2. Positive (NS) } \\
\text { 3. Negative (S) }\end{array}$ \\
\hline & & & & HCRU & $\begin{array}{l}\text { 1. Outpatient visits } \\
\text { 2. Hospitalizations } \\
\text { 3. Emergency room visits }\end{array}$ & $\begin{array}{l}\text { 1. Negative (NS) } \\
\text { 2. Positive (NS) } \\
\text { 3. Neutral }\end{array}$ \\
\hline & & & & Utilization & 1. Drug utilization & 1. Positive (S) \\
\hline \multirow{2}{*}{$\begin{array}{l}\text { Tunis et al. } \\
2006^{73}\end{array}$} & \multirow[t]{2}{*}{ ST } & \multirow[t]{2}{*}{ Schizophrenia } & \multirow{2}{*}{$\begin{array}{l}\text { Randomized } \\
\text { controlled trial }\end{array}$} & Clinical & 1. Clinical outcomes & 1. Negative (S) \\
\hline & & & & Economic & $\begin{array}{l}\text { 1. Total costs } \\
\text { 2. Pharmacy costs }\end{array}$ & $\begin{array}{l}\text { 1. Neutral } \\
\text { 2. Positive (S) }\end{array}$ \\
\hline \multirow[t]{2}{*}{$\begin{array}{l}\text { Zhang et al. } \\
2012^{81}\end{array}$} & \multirow[t]{2}{*}{ ST } & \multirow[t]{2}{*}{ Epilepsy } & \multirow[t]{2}{*}{$\begin{array}{l}\text { Retrospective } \\
\text { observational }\end{array}$} & Economic & $\begin{array}{l}\text { 1. Medical costs } \\
\text { 2. Pharmacy costs }\end{array}$ & $\begin{array}{l}\text { 1. Negative (NS) } \\
\text { 2. Positive (S) }\end{array}$ \\
\hline & & & & HCRU & $\begin{array}{l}\text { 1. Outpatient visits } \\
\text { 2. Hospitalizations } \\
\text { 3. Emergency room visits }\end{array}$ & $\begin{array}{l}\text { 1. Negative (NS) } \\
\text { 2. Neutral } \\
\text { 3. Neutral }\end{array}$ \\
\hline $\begin{array}{l}\text { Blomquist et al. } \\
2010^{32}\end{array}$ & ST & Gastrointestinal-related diagnoses & $\begin{array}{l}\text { Retrospective } \\
\text { controlled } \\
\text { before-after }\end{array}$ & Economic & 1. Pharmacy costs & 1. Positive (S) \\
\hline \multirow[t]{4}{*}{$\begin{array}{l}\text { Null et al. } \\
2016^{64}\end{array}$} & \multirow{2}{*}{$\begin{array}{c}\text { ST } \\
\text { (Medicare } \\
\text { Advantage) } \\
\end{array}$} & \multirow{4}{*}{$\begin{array}{l}\text { Painful diabetic peripheral } \\
\text { neuropathy or postherpetic } \\
\text { neuralgia or fibromyalgia }\end{array}$} & \multirow[t]{4}{*}{$\begin{array}{l}\text { Time-series } \\
\text { analysis }\end{array}$} & Economic & $\begin{array}{l}\text { 1. Total costs } \\
\text { 2. Medical costs }\end{array}$ & $\begin{array}{l}\text { 1. Positive (S) } \\
\text { 2. Neutral }\end{array}$ \\
\hline & & & & Utilization & 1. Drug utilization & 1. Positive (NS) \\
\hline & \multirow[t]{2}{*}{$\begin{array}{c}\mathrm{ST} \\
\text { (Commercial) }\end{array}$} & & & Economic & $\begin{array}{l}\text { 1. Total costs } \\
\text { 2. Medical costs }\end{array}$ & $\begin{array}{l}\text { 1. Positive (NS) } \\
\text { 2. Positive (NS) }\end{array}$ \\
\hline & & & & Utilization & 1. Drug utilization & 1. Positive (S) \\
\hline $\begin{array}{l}\text { Cotter et al. } \\
2011^{41}\end{array}$ & ST & Type 2 diabetes & $\begin{array}{l}\text { Retrospective } \\
\text { observational }\end{array}$ & Economic & 1. Pharmacy costs & 1. Positive (S) \\
\hline $\begin{array}{l}\text { Lin et al. } \\
2012^{58}\end{array}$ & ST & Breast and lung cancer & $\begin{array}{l}\text { Retrospective } \\
\text { observational }\end{array}$ & Clinical & 1. Clinical outcomes & 1. Negative (S) \\
\hline \multirow{3}{*}{$\begin{array}{l}\text { Suehs et al. } \\
2015^{72}\end{array}$} & \multirow[t]{3}{*}{ ST } & \multirow{3}{*}{$\begin{array}{l}\text { Attention deficit/hyperactivity } \\
\text { disorder }\end{array}$} & \multirow{3}{*}{$\begin{array}{l}\text { Retrospective } \\
\text { observational }\end{array}$} & Adherence & 1. Medication adherence & 1. Negative (S) \\
\hline & & & & Economic & $\begin{array}{l}\text { 1. Total costs } \\
\text { 2. Medical costs } \\
\text { 3. Pharmacy costs }\end{array}$ & $\begin{array}{l}\text { 1. Positive (S) } \\
\text { 2. Positive (NS) } \\
\text { 3. Positive (S) }\end{array}$ \\
\hline & & & & Utilization & 1. Drug utilization & 1. Positive (S) \\
\hline \multirow{2}{*}{$\begin{array}{l}\text { Harman et al. } \\
2016^{45}\end{array}$} & \multirow[t]{2}{*}{ ST } & \multirow{2}{*}{$\begin{array}{l}\text { Rheumatoid arthritis/multiple } \\
\text { sclerosis }\end{array}$} & \multirow{2}{*}{$\begin{array}{l}\text { Retrospective } \\
\text { observational }\end{array}$} & Economic & 1. Pharmacy costs & 1. Positive (U) \\
\hline & & & & Utilization & 1. Drug utilization & 1. Positive (U) \\
\hline \multicolumn{7}{|c|}{ Effect of Step Therapy/Prior Authorization } \\
\hline \multirow{3}{*}{$\begin{array}{l}\text { Louder et al. } \\
2011^{57}\end{array}$} & \multirow[t]{3}{*}{ ST/PA } & \multirow{3}{*}{$\begin{array}{l}\text { Osteoarthritis or rheumatoid } \\
\text { arthritis }\end{array}$} & \multirow{3}{*}{$\begin{array}{l}\text { Retrospective } \\
\text { observational }\end{array}$} & Clinical & 1. Clinical outcomes & 1. Negative (S) \\
\hline & & & & Economic & 1. Medical costs & 1. Negative $(S)$ \\
\hline & & & & Utilization & 1. Drug utilization & 1. Positive (S) \\
\hline West et al. & $\mathrm{ST} / \mathrm{PA}$ & Psychiatric patients & Cross sectional & Clinical & 1. Clinical outcomes & 1. Negative $(\mathrm{S})$ \\
\hline & & & & Utilization & 1. Drug utilization & 1. Positive (S) \\
\hline $\begin{array}{l}\text { Nau et al. } \\
200765\end{array}$ & ST/PA & NR & Cross sectional & $\mathrm{PROs}$ & $\begin{array}{l}\text { 1. Difficulties related to } \\
\text { PA or ST }\end{array}$ & 1. Negative (U) \\
\hline $\begin{array}{l}\text { Farley et al. } \\
2008^{42}\end{array}$ & ST/PA & $\begin{array}{l}\text { Overall cohort and schizophrenia } \\
\text { subgroup }\end{array}$ & $\begin{array}{l}\text { Time-series } \\
\text { analysis }\end{array}$ & Economic & $\begin{array}{l}\text { 1. Medical costs } \\
\text { 2. Pharmacy costs }\end{array}$ & $\begin{array}{l}\text { 1. Negative }(\mathrm{U}) \\
\text { 2. Positive }(\mathrm{S})\end{array}$ \\
\hline & & & & Utilization & 1. Drug utilization & 1. Negative (NS) \\
\hline $\begin{array}{l}\text { Seabury et al. } \\
201467 \text {,a }\end{array}$ & ST/PA & Major depressive disorder & $\begin{array}{l}\text { Retrospective } \\
\text { observational }\end{array}$ & Economic & $\begin{array}{l}\text { 1. Total costs } \\
\text { 2. Medical costs } \\
\text { 3. Pharmacy costs }\end{array}$ & $\begin{array}{l}\text { 1. Neutral } \\
\text { 2. Negative (S) } \\
\text { 3. Neutral }\end{array}$ \\
\hline & & & & HCRU & 1. Hospitalizations & 1. Negative (NS) \\
\hline
\end{tabular}




\section{APPENDIX A Study Characteristics (continued)}

\begin{tabular}{|c|c|c|c|c|c|c|}
\hline Reference & $\begin{array}{l}\text { Restriction } \\
\text { Type }\end{array}$ & Indication & Study Design & $\begin{array}{l}\text { Outcome } \\
\text { Type }\end{array}$ & Outcome & $\begin{array}{l}\text { Direction of } \\
\text { Association }\end{array}$ \\
\hline \multirow{9}{*}{$\begin{array}{l}\text { Shen et al. } \\
2016^{60}\end{array}$} & \multirow[t]{9}{*}{$\mathrm{ST} / \mathrm{PA}$} & \multirow{3}{*}{$\begin{array}{l}\text { Low-income subsidized users of } \\
\text { oral hypoglycemic agents }\end{array}$} & \multirow{9}{*}{$\begin{array}{l}\text { Retrospective } \\
\text { observational }\end{array}$} & Adherence & 1. Medication adherence & 1. Neutral \\
\hline & & & & Economic & 1. Pharmacy costs & 1. Positive (U) \\
\hline & & & & Utilization & 1. Drug utilization & 1. Positive (U) \\
\hline & & \multirow{3}{*}{$\begin{array}{l}\text { Low-income subsidized users of } \\
\text { statins }\end{array}$} & & Adherence & 1. Medication adherence & 1. Neutral \\
\hline & & & & Economic & 1. Pharmacy costs & 1. Positive (U) \\
\hline & & & & Utilization & 1. Drug utilization & 1. Positive (U) \\
\hline & & \multirow{3}{*}{$\begin{array}{l}\text { Low-income subsidized users of } \\
\text { renin-angiotensin system } \\
\text { antagonists }\end{array}$} & & Adherence & 1. Medication adherence & 1. Negative (U) \\
\hline & & & & Economic & 1. Pharmacy costs & 1. Positive (U) \\
\hline & & & & Utilization & 1. Drug utilization & 1. Positive (U) \\
\hline \multicolumn{7}{|c|}{ Effect of Restrictions on No Claims vs. Approved Claims } \\
\hline $\begin{array}{l}\text { Bergeson et al. } \\
2013^{33}\end{array}$ & PA & Type 2 diabetes & $\begin{array}{l}\text { Retrospective } \\
\text { observational }\end{array}$ & Economic & $\begin{array}{l}\text { 1. Total costs } \\
\text { 2. Medical costs } \\
\text { 3. Pharmacy costs }\end{array}$ & $\begin{array}{l}\text { 1. Positive (NS) } \\
\text { 2. Positive (NS) } \\
\text { 3. Negative (S) }\end{array}$ \\
\hline \multicolumn{7}{|c|}{ Effect of Restrictions on Different Disease States } \\
\hline \multirow{8}{*}{$\begin{array}{l}\text { Johnston et al. } \\
2012^{53}\end{array}$} & $\mathrm{PA}$ & \multirow{2}{*}{$\begin{array}{l}\text { Painful diabetic peripheral } \\
\text { neuropathy or postherpetic } \\
\text { neuralgia }\end{array}$} & \multirow{8}{*}{$\begin{array}{l}\text { Retrospective } \\
\text { observational }\end{array}$} & Economic & 1. Medical costs & 1. Positive (S) \\
\hline & ST & & & Economic & 1. Medical costs & 1. Negative (NS) \\
\hline & $\mathrm{PA}$ & \multirow[t]{2}{*}{ Fibromyalgia } & & Economic & 1. Medical costs & 1. Positive (NS) \\
\hline & ST & & & Economic & 1. Medical costs & 1. Negative (NS) \\
\hline & $\mathrm{PA}$ & \multirow{2}{*}{$\begin{array}{l}\text { Painful diabetic peripheral } \\
\text { neuropathy or postherpetic } \\
\text { neuralgia }\end{array}$} & & Utilization & 1. Drug utilization & 1. Positive (S) \\
\hline & ST & & & Utilization & 1. Drug utilization & 1. Negative (NS) \\
\hline & PA & \multirow[t]{2}{*}{ Fibromyalgia } & & Utilization & 1. Drug utilization & 1. Positive (S) \\
\hline & ST & & & Utilization & 1. Drug utilization & 1. Positive (S) \\
\hline \multirow{2}{*}{$\begin{array}{l}\text { LaPensee et al. } \\
2010^{56}\end{array}$} & \multirow[t]{2}{*}{ ST } & \multirow[t]{2}{*}{ Anxiety/depression } & \multirow[t]{2}{*}{ Cross-sectional } & Adherence & 1. Medication adherence & 1. Negative $(\mathrm{S})$ \\
\hline & & & & $\mathrm{PROs}$ & 1. Patient satisfaction & 1. Negative $(\mathrm{S})$ \\
\hline
\end{tabular}

a Seabury et al. (2014) reported 2 groups: 1 group was exposed to PA restriction and the other group was exposed to PA and ST restrictions.

$H C R U=$ health care resource utilization; $N R=$ not reported; $N S=$ not significant; $P A=$ prior authorization; $P R O=$ patient-reported outcome; $S=$ significant; $S T=$ step therapy; $U=$ unclear. 
APPENDIX B Quality Assessment of Nonrandomized Studies by Newcastle-Ottawa Scale

\begin{tabular}{|c|c|c|c|c|c|c|c|c|c|}
\hline \multirow{2}{*}{$\begin{array}{l}\text { Author } \\
\text { Cohort studies }\end{array}$} & \multicolumn{4}{|c|}{ Selection } & \multirow[t]{2}{*}{ Comparability } & \multicolumn{3}{|c|}{ Exposure } & \multirow[t]{2}{*}{ Number of Stars } \\
\hline & 1 & 2 & 3 & 4 & & 1 & 2 & 3 & \\
\hline Lu et al. $2011^{55}$ & $\star$ & $\star$ & $\star$ & ts & $\star \star$ & $\star$ & $\star$ & $\dot{s}$ & 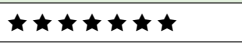 \\
\hline Margolis et al. $2010^{62}$ & $\star$ & 准 & $\star$ & 头 & $\star \star$ & $\star$ & $\star$ & 头 & 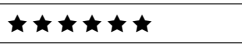 \\
\hline Mark et al. $2010^{19}$ & $\star$ & 武 & $\star$ & 放 & 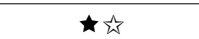 & $\star$ & $\star$ & 头 & $\star \star \star \star \star \star$ \\
\hline Walthour et al. $2010^{79}$ & $\star$ & 必 & $\star$ & 文 & 故坛 & $\star$ & $\star$ & t心 & $\star \star \star \star$ \\
\hline Margolis et al. $2009^{61}$ & $\star$ & 必 & $\star$ & 市 & $\star \star$ & $\star$ & $\star$ & $\star$ & 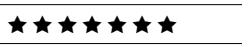 \\
\hline Adams et al. $2009^{37}$ & $\star$ & 必 & $\star$ & 必 & $\star \star$ & $\star$ & $\star$ & 头 & 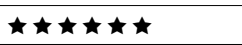 \\
\hline Zhang et al. $2009^{78}$ & $\star$ & 必 & $\star$ & 幽 & $\star \star$ & $\star$ & $\star$ & 幽 & 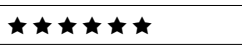 \\
\hline Mark et al. $2009^{21}$ & $\star$ & $\star$ & $\star$ & 齿 & $\star \star$ & $\star$ & $\star$ & 考 & 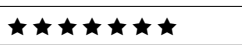 \\
\hline Soumerai et al. $2008^{71}$ & $\star$ & 为 & $\star$ & 为 & $\star \star$ & $\star$ & $\star$ & ts & 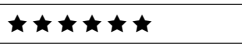 \\
\hline Siracuse et al. $2008^{70}$ & $\star$ & 幽 & $\star$ & 出 & 故㑔 & $\star$ & $\star$ & 考 & $\star \star \star \star \star$ \\
\hline Sun et al. $2007^{75}$ & $\star$ & 必 & $\star$ & 文 & 站坛 & $\star$ & $\star$ & 光 & $\star \star \star \star$ \\
\hline Yokoyama et al. $2007^{77}$ & $\star$ & 幽 & $\star$ & 出 & $\star \star$ & $\star$ & $\star$ & 去 & 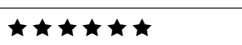 \\
\hline Hartung et al. $2006^{46}$ & $\star$ & 必 & $\star$ & 必 & 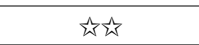 & $\star$ & $\star$ & 头 & $\star \star \star \star$ \\
\hline Dunn et al. $2006^{44}$ & $\star$ & $\star$ & $\star$ & 头 & 论场 & $\star$ & $\star$ & 必 & $\star \star \star \star \star$ \\
\hline Carroll et al. $2006^{38}$ & $\star$ & 弐 & $\star$ & 齿 & $\star \star$ & 次 & $\star$ & 考 & $\star \star \star \star \star \star$ \\
\hline Risser et al. 200563 & $\star$ & $\star$ & $\star$ & 为 & $\star$ 死 & $\star$ & $\star$ & ts & 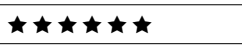 \\
\hline Gleason et al. $2005^{39}$ & $\star$ & $\star$ & $\star$ & 齿 & 站场 & $\star$ & $\star$ & ts & $\star \star \star \star \star$ \\
\hline Simeone et al. $2010^{69}$ & $\star$ & $\star$ & $\star$ & t t & 故族 & $\star$ & $\star$ & 必 & $\star \star \star \star \star \star$ \\
\hline Louder et al. $2011^{57}$ & $\star$ & 必 & $\star$ & ts & $\star \Delta$ & $\star$ & $\star$ & 幽 & $\star \star \star \star \star \star$ \\
\hline Suehs et al. $2015^{72}$ & $\star$ & 武 & $\star$ & 必 & $\star \Delta$ & $\star$ & $\star$ & 弐 & 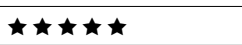 \\
\hline Johnston et al. $2014^{23}$ & $\star$ & 弐 & $\star$ & 资 & $\star \star$ & $\star$ & $\star$ & 去 & 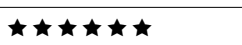 \\
\hline Garcia et al. 201448 & $\star$ & $\star$ & $\star$ & 齿 & 故公 & $\star$ & th & 光 & $\star \star \star \star$ \\
\hline Clark et al. 201424 & $\star$ & 幽 & $\star$ & 功 & 故教 & $\star$ & $\star$ & 头 & $\star \star \star \star$ \\
\hline Suehs et al. 201468 & $\star$ & 必 & $\star$ & 考 & $\star \star$ & $\star$ & $\star$ & 光 & 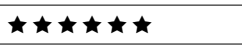 \\
\hline Placzek et al. $2015^{66}$ & $\star$ & $\star$ & $\star$ & 头 & $\star \star$ & $\star$ & $\star$ & 头 & 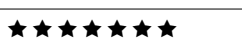 \\
\hline Ben-Joseph et al. 201436 & $\star$ & 武 & $\star$ & 站 & 故坛 & $\star$ & $\star$ & 老 & $\star \star \star \star$ \\
\hline Goldman et al. 201447 & 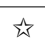 & $\star$ & $\star$ & 必 & $\star \star$ & $\star$ & 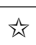 & 弐 & $\star \star \star \star \star \star$ \\
\hline Keast et al. 201451 & $\star$ & 就 & $\star$ & 齿 & 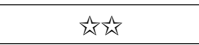 & $\star$ & 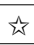 & 光 & $\star \star \star$ \\
\hline Starner et al. $2014^{22}$ & $\star$ & 幽 & $\star$ & 出 & $\star \star$ & $\star$ & t & 者 & 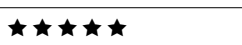 \\
\hline Lin et al. $2012^{58}$ & $\star$ & $\star$ & $\star$ & 必 & $\star \star$ & $\star$ & $\star$ & 头 & 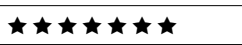 \\
\hline Brown et al. $2013^{34}$ & $\star$ & 武 & $\star$ & 放 & $\star \star$ & $\star$ & t & 莯 & $\star \star \star \star \star \star$ \\
\hline Bergeson et al. $2013^{33}$ & $\star$ & 武 & $\star$ & 必 & $\star \star$ & $\star$ & $\star$ & $\star$ & 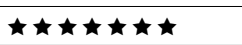 \\
\hline Udall et al. $2013^{80}$ & $\star$ & 幽 & $\star$ & 资 & $\star \star$ & $\star$ & $\star$ & 者 & 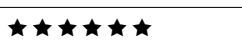 \\
\hline Gleason et al. $2013^{49}$ & $\star$ & 幽 & $\star$ & 步 & 故㑔 & $\star$ & $\star$ & 老 & $\star \star \star \star \star$ \\
\hline Williams et al. $2012^{20}$ & $\star$ & $\star$ & $\star$ & 光 & 站坛 & $\star$ & $\star$ & 光 & $\star \star \star \star \star \star$ \\
\hline Starner et al. $2012^{10}$ & $\star$ & 弐 & $\star$ & 步 & 卖育 & $\star$ & $\star$ & 者 & $\star \star \star \star$ \\
\hline Harman et al. $2016^{45}$ & $\star$ & $\star$ & $\star$ & 站 & 站放 & $\star$ & 就 & 头 & $\star \star \star \star$ \\
\hline \multicolumn{10}{|l|}{ Case-control study } \\
\hline Sun et al. $2008^{74}$ & $\star$ & $\star$ & $\star$ & $\star$ & 弐约 & $\star$ & $\star$ & 老 & 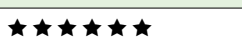 \\
\hline
\end{tabular}

Note: A study can be awarded a maximum of 1 star for each numbered item within the Selection and Exposure categories. A maximum of 2 stars can be given for Comparability. A higher number of total stars depicts better quality for the study. 